\title{
Managerial Discretion and the Capital Structure Dynamics
}

\author{
Ayla Kayhan ${ }^{*}$ \\ Louisiana State University
}

March 21, 2008

\begin{abstract}
This paper examines the effect of managerial discretion on capital structure dynamics. Analyses of financing decisions indicate that managers with more discretion prefer issuing equity over debt. Examination of leverage changes suggests that increases in debt ratios due to positive and negative financial deficits are greater for managers with high discretion. Furthermore, when managers have highdiscretion, debt changes seem to be more sensitive to issuance activities than to repurchase activities. For high-discretion managers, market timing activities (equity issuance following increases in stock prices) and the passive response to stock price appreciations, result in greater declines in debt ratios. Finally, while firms tend to rebalance their capital structures over time regardless of the level of managerial discretion, the speed of target adjustment is much slower for high-discretion managers.
\end{abstract}

\footnotetext{
* Department of Finance, Louisiana State University, Baton Rouge, LA 70803, e-mail: akayhan@lsu.edu, phone: (225) 578-6236. This paper is previously titled as Managerial Entrenchment and the Debt-Equity Choice.

I appreciate the comments from Lucian Bebchuk, Vidhan Goyal, Peter MacKay, Cagatay Koc, Roberto Wessels, seminar participants at SEC and participants at the 2007 ANU Summer Camp. Add more thanks.
} 


\title{
Managerial Discretion and the Capital Structure Dynamics
}

March 21, 2008

\begin{abstract}
This paper examines the effect of managerial discretion on capital structure dynamics. Analyses of financing decisions indicate that managers with more discretion prefer issuing equity over debt. Examination of leverage changes suggests that increases in debt ratios due to positive and negative financial deficits are greater for managers with high discretion. Furthermore, when managers have highdiscretion, debt changes seem to be more sensitive to issuance activities than to repurchase activities. For high-discretion managers, market timing activities (equity issuance following increases in stock prices) and the passive response to stock price appreciations, result in greater declines in debt ratios. Finally, while firms tend to rebalance their capital structures over time regardless of the level of managerial discretion, the speed of target adjustment is much slower for high-discretion managers.
\end{abstract}




\section{Managerial Discretion and the Capital Structure Dynamics}

Following Jensen and Meckling (1976), the influence of managerial incentives on capital structure choices has attracted considerable attention. Theories have posited that managers prefer lower debt ratios to reduce risk and protect their undiversified human capital, to alleviate the pressure that comes with interest payment commitments, or to benefit from opportunities associated with running a less levered firm where investment capital can be easily raised. ${ }^{1}$ Others have argued the contrary, pointing out that managers prefer higher leverage to reduce the probability of a takeover either by reducing the acquirers' interest due to transfer of value from shareholders to debt holders or by inflating their voting power. ${ }^{2}$ Furthermore, managers may choose higher leverage to convince investors of their ability to generate sufficient earnings to repay their debt. ${ }^{3}$ Finally, recent survey evidence of Graham and Harvey (2001) indicate that managers regard financial flexibility as the most important factor in their capital structure decisions.

Empirical research on this issue suggests that managers with discretion, who are protected from the pressures of internal and external governance mechanisms (i.e., capable of acting in their self-interest), prefer lower leverage ratios. ${ }^{4}$ However, given

\footnotetext{
${ }^{1}$ Fama (1980) argues that it is in managers' best interest to avoid their firms' failure, as the future rental rate on their undiversified human capital depends on their firms' success. In Jensen (1986)'s free cash flow argument, payouts (in the form of interest payments) reduce the resources under the management, thereby reducing managers' power and increasing the likelihood of monitoring by the capital markets. Hart and Moore (1995) and Zwiebel (1996) argue that debt limits managers' ability to finance future investment.

${ }^{2}$ Israel (1992) argues that by issuing risky debt the current management in the target firm transfers some of the value from equity holders to the debt holders in exchange for private benefits of control, which lowers the acquirer's premium. Harris and Raviv (1988) and Stulz (1988) argue that managers increase their leverage to defend takeover challenges by increasing the concentration of their shareholdings, which enables them to have greater control in their firms.

${ }^{3}$ For example, Ross (1977) argues that when managers possess inside information, their choice of financial structure signals information to the market, and in competitive equilibrium, firm values will rise with leverage since increasing leverage increases the market's perception of value.

${ }^{4}$ Friend and Lang (1988) and Mehran (1992) find that managers with discretion tend to make capital structure decisions that are more conservative, i.e., they favor lower leverage. Consistent with this, Berger et al. (1997) show that leverage levels are lower when managers do not face pressure from disciplining mechanisms such as market for corporate control. In a more specific context, Garvey and Hanka (1999) show that managers who receive negative shocks to their entrenchment (a hostile takeover threat) tend to take on more debt. Safieddine and Titman (1999) find that managers increase their
} 
the opposing theoretical views on the relation between managerial discretion and the choice of capital structure, the empirical evidence supporting these views is hard to generalize, $^{5}$ and we know little about how managers with discretion achieve their desired capital structure.

The goal of this paper is to examine the effect of managerial discretion on capital structure dynamics. First, I analyze the patterns between financing activities and variables that are associated with managerial discretion. Second, I investigate how managerial discretion influences the way debt ratios respond to firms' history of financial deficits, stock price performances, and their tendencies to maintain a target capital structure. With this analysis, I provide a set of mechanisms through which highdiscretion managers can achieve a personally favored capital structure while responding to firms' external capital needs and changes in market conditions. To the best of my knowledge, this is the first paper that explicitly examines the effect of managerial discretion on firms' capital structure dynamics.

I define managerial discretion as the extent to which managers are able to pursue their self-interest which could be due to multitude of factors such as the lack of effective monitoring by the board or by the blockholders or could simply be the result of managerial attributes. To capture these characteristics, I consider the level of beneficial ownership, board size, director age, CEO-Chairman duality, board independence, and CEO age. Compared to the existing literature, these proxies cover a wider range of governance measures, the sample is composed of a larger spectrum of firms (about 5,835 firm clusters), and is compiled from a more recent time period (from 1988 to 2005).

\footnotetext{
leverage when they become takeover targets not to entrench themselves but to commit to making improvements. Earlier versions of this paper presented evidence that shows that managers with discretion prefer low debt ratios.

${ }^{5}$ Friend and Lang (1988) examine the effect of managerial ownership on capital structure using 984 firms from 1979 to 1983 . Mehran (1992) investigates the relationship between the firms' capital structure and executive incentive plans, managerial equity investment, and monitoring by the major shareholders using 124 randomly selected manufacturing firms during 1979-1980. Berger et al. (1997) use a dataset of 452 firms between 1984 and 1991 that are drawn from Forbes magazine rankings of the 500 largest U.S. public corporations.
} 
I begin by investigating the relation between financing activities and the proxies for managerial discretion. When firms have free cash flow, managerial discretion might enhance firms' tendencies to accumulate their earnings (rather than paying them out) and achieve a conservative capital structure, which improves their job security and their ability to raise additional funds for their investments. ${ }^{6}$ When firms need external financing, managers' preference for raising debt versus equity is likely to depend on the difficulty of convincing the board and the shareholders to raise capital and the consequences of the financing decisions on their control over the firm. For example, when there is a possibility of a takeover challenge, managers may prefer to issue debt and increase their debt ratios if they need external capital, even though they personally favor lower leverage ratios (Zwiebel (1996)). On the other hand, if managers' job security is not threatened by a takeover pressure, they may prefer to issue equity which would allow them to raise capital for their investments while reducing their debt ratios. However, equity issues result in greater market scrutiny. ${ }^{7}$ Since the market scrutiny costs are likely to be greater for high-discretion managers, issuing debt may be more appealing, leading these managers to choose debt over equity to finance their external capital needs.

The findings suggest that, for the most part, managerial discretion proxies are associated with actions resulting in enhancing resources available for investment projects either by using internally generated capital (e.g., director age and CEO age) or by raising more external capital (e.g., board size, CEO-chairman duality, and percentage of outsiders on the board). The results on the issuance regressions consistently predict preference for equity over debt when firms have higher levels of managerial discretion. In the case of repurchase decisions proxies measuring higher levels of managerial discretion seem to be associated with a stronger preference for debt over equity in repurchasing capital but the evidence is somewhat weaker.

\footnotetext{
${ }^{6}$ Donaldson (1961) was the first to observe that firms prefer internal capital over external financing.

${ }^{7}$ Almazan et al. (2006) show that managers may decide not to issue equity to avoid scrutiny that comes with greater exposure to equity markets.
} 
I extend the analysis by examining the role of managerial discretion in determining changes in debt ratios in response to firms' accumulated financing activities taking into account that firms might be following a target capital structure. More specifically, I examine how leverage ratios respond to firms' external financing needs (proxied for by financial deficits), changes in market conditions (proxied for by cumulative stock returns and market timing variables), and the extent to which their debt ratios deviate from their targets (proxied for by leverage deficits) by endogenously selecting the observations into the high- and low-discretion regimes based on the latent discretion characteristic. 8 Implementation of this estimation technique, which allows me to take into account the multiple dimensions of the managerial discretion characteristic without relying on an ad hoc summary variable, addresses one of the major concerns in the corporate governance literature.

Next, I describe these factors (i.e., financial deficits, cumulative stock returns, market timing, and leverage deficits) that determine the changes in debt ratios and discuss how managerial discretion affects the extent to which the debt ratios respond to these factors.

Financial Deficits: As argued above, high-discretion managers may respond differently to firms' financial deficits (i.e., external financing needs or external financing surplus) because they are concerned about their job security, the flexibility of undertaking new investments, and the market scrutiny. ${ }^{9}$ The results indicate that the response in leverage ratio to firms' financial deficits is greater for high-discretion managers. Furthermore, findings suggest that debt changes are more sensitive to issuance activities than repurchase activities when managers have high-discretion, consistent with the findings on financing decisions.

Cumulative stock returns and market timing: Changes in market conditions (i.e., firms' recent stock price performances) are likely to affect debt ratios through two

\footnotetext{
${ }^{8}$ See Maddala (1986). This estimation technique, which is called the endogenous switching model with unknown sample separation, endogenously selects the observations into different regimes based on observed characteristics that are correlated with the latent characteristic.

${ }^{9}$ Shyam-Sunder and Myers (1999) and Frank and Goyal (2003) examine the extent to which firms' capital structure change as a results of their external financing needs.
} 
related factors. First, the decline in leverage ratios following increases in stock prices is likely to be greater for high-discretion managers due to their unwillingness to undo the stock price induced changes in their leverage ratio because of their personal taste for lower leverage ratios. ${ }^{10}$ Second, firms with high-discretion managers may have greater tendencies to raise capital when the equity market is more favorable (generally referred to as market timing) because the increase in stock price makes it more likely that the high-discretion managers get approval from the board or face lower scrutiny costs for issuing equity. ${ }^{11}$ The results indicate that managers with more discretion in their financing choices tend to achieve lower debt ratios either by not engaging any rebalancing in their debt ratios after favorable stock price performances or by actively issuing equity following improvements in their market valuations, i.e. timing the equity markets. ${ }^{12}$ This evidence is one of the most significant contributions of the paper, as it provides an alternative explanation to market timing activity which is generally attributed to the investor irrationality where rational managers take advantage of the investor exuberance by issuing equity when (they think) their stock is overvalued.

Leverage deficits: Depending on the extent to which firms follow a target capital structure, they will increase (decrease) their leverage when their observed leverage is lower (higher) than their target leverage and this response is likely to vary with the level of managerial discretion. The results strongly suggest that firms tend to rebalance their capital structures over time regardless of the level of managerial discretion. However, the speed at which firms move towards their targets is much slower in the highdiscretion regime. Furthermore, the asymmetry between the leverage increasing and leverage decreasing adjustments towards a target ratio seem to be less relevant for the high-discretion regime.

\footnotetext{
${ }^{10}$ Welch (2004) shows that firms experiencing large stock returns tend to have lower debt ratios.

${ }^{11}$ Hermalin and Weisbach (1998) argue that board independence declines with better performance. Novaes and Zingales (1995) show how stock price performance influences managers' financing decisions when they have discretion in firms financing policies.

${ }^{12}$ See, for example, Baker and Wurgler (2002). Early studies on firms' equity issuance behavior include Taggart (1977), Marsh (1982) and Asquith and Mullins (1986). See Ritter (2002) for a detailed list of papers.
} 
Two sets of robustness analyses are implemented. The first set addresses the potential endogeneity concerns between the managerial discretion proxies and the financing decisions. The second set addresses the robustness of the endogenous switching regression model in predicting the likelihood of being in either low- or highdiscretion regime. The results for the endogeneity tests suggest that the positive correlation between CEO discretion and financing variables is consistent with causation running from discretion to financing decisions. The results for the second set of robustness analyses confirm that the predictive power of the switching regression model in separating the low- and high-discretion regimes is robust to the considerations of antitakeover provisions, incentive measures (i.e., CEO stock holdings, and CEO option holdings), and other firm characteristics (e.g., firm size).

This paper places itself in two strands of literature. First, it adds on to the literature on corporate governance that recognizes that firms' capital structure policies are the results of managers' decisions rather than considering them as solutions to the free cash flow problem. ${ }^{13}$ Second, it adds on the recent debate on the existence of an optimal capital structure and firms' tendencies to maintain a target debt ratio by showing that managerial discretion has a significant role on firms' capital structure dynamics. ${ }^{14}$

The remainder of the paper is organized as follows. Section 1 describes the measurement of the discretion, capital structure, and financing proxies, data, and the sample. Section 2 reports the analyses of financing decisions under the influence of managerial discretion. Section 3 reports the analysis of the effect of managerial discretion on the changes in capital structure due to firms' history of financing decisions and market conditions. Section 4 presents robustness analyses. Section 5 concludes.

\footnotetext{
${ }^{13}$ In the free cash flow stories (e.g., Grossman and Hart (1982), Stulz (1990), and Williamson (1988)), the debt ratio is typically set ex ante in a manner that maximizes the firm value with the help of a "discipliner" that is present ex ante (and generally absent ex post). Theoretical papers recognizing managers' preferences on capital structure decisions include Zwiebel (1996), and more recently, Morellec et al. (2008) and Berk et al. (2007). Jung et al. (1996) and more recently, Frank and Goyal (2007) and Litov and John (2006) show that managerial preferences effect firms' leverage decisions.

${ }^{14}$ See, for example, Flannery and Rangan (2006), Kayhan and Titman (2007), Lemmon et al. (2008), for recent evidence on the extent to which firms adjust towards a target capital structure. Most recently, Strebulaev (2007) shows that because of frictions firms adjust their debt ratios infrequently and that in a dynamic economy the leverage of most firms is likely to differ from the optimum leverage at the time of readjustment.
} 


\section{Measurement, data, and sample}

\section{A. Measurement of managerial discretion:}

In this paper managerial discretion is defined as a latent characteristic representing multiple dimensions of corporate governance that affect managers' ability to act in their self interest. I identify various proxies including managerial attributes, board structure, and blockholder ownership, and hypothesize how they contribute to managers' discretion levels. These proxies, which include chairman CEO duality, managers' age, percentage of ownership by beneficial shareholders, board size, board composition, and directors' age are discussed below with their predicted associations with managerial discretion.

\section{CEO-Chairman duality}

Chairman CEOs are likely to have high discretion because their unique position is likely to yield greater latitude to them when they make financing and capital structure decisions. Specifically, Chairman CEOs are likely to be empowered to act with determination and have far more influence over other directors which will result in their ability to withstand pressure better - especially when short-term changes do not pay off - than non-chairman CEOs, resulting in greater discretion. ${ }^{15}$ Chairman CEOs are identified with an indicator variable that takes the value 1 when the CEO carries both titles and zero otherwise.

\section{CEO age}

Older CEOs are likely to have increased control over internal monitoring mechanisms due to their accumulated experience and reputation. Consequently, CEO age, which

\footnotetext{
${ }^{15}$ Note that the chairman CEO duality is likely to bring advantages to information sharing costs between the CEO and the chairman and that the board is likely to focus less on constant watchdog evaluation of the CEO than making him or her successful. However, this allows for little transparency into the CEO's acts, and as such their actions can go unmonitored, it paves the way for scandal and corruption. Goyal and Park (2002) find that the sensitivity of CEO turnover to firm performance is significantly lower when the CEOs are also the chairman. Brickley et al. (1997) document that firms combining the CEO and chairman duties perform no worse than those that do not combine them.
} 
could also be thought of an alternate measure of CEO tenure, is associated with higher discretion levels. For example, in the context of CEO tenure Hermalin and Weisbach (1998)'s model show that CEOs with long tenure, who have proved themselves to be considerably better than the expected value of replacements, will have greater bargaining power against the board and hence will be subject to less scrutiny. ${ }^{16}$ One could also argue that long period of service in office may indicate greater misalignment in managerial incentives due to their greater job security (i.e., low probability of losing the position), and hence higher levels of managerial discretion. I use logarithm form of CEO age because its effect is likely to accumulate over time at a decreasing rate.

\section{Board composition}

A large number of outside directors on the board and the board committees could indicate that the management is likely to be challenged with active monitoring (i.e., managers have low discretion). ${ }^{17}$ For a director, however, having a reputation for not making any trouble for CEOs is potentially valuable. As a result, an outside director, with limited access to valuable specific information about the organization's activities, might side with the management enhancing the level of its discretion (Hermalin and Weisbach (2003)). ${ }^{18}$ Board composition is defined as the percentage of outside directors on the board.

\section{Board size}

A large board is indicative of less effective monitoring of the management (i.e., managers have high discretion) due to agency problems (such as director free-riding),

\footnotetext{
${ }^{16}$ Hermalin and Weisbach (1988) document that as CEOs approach their retirement they tend to appoint insiders to the board which will result in less scrutiny. They also find that when firms perform poorly they tend to replace inside directors with the outside directors which is likely to decrease their power.

${ }^{17}$ Fama (1980) and Fama and Jensen (1983) emphasize that directors have incentives to build reputations as expert monitors. Weisbach (1988) shows that, compared to firms with insider-dominated boards, firms with outsider-dominated board tend to have stronger association between prior performance and the probability of CEO turnover. Brickley et al. (1994) find that stock market reaction to announcements of poison pill is positive when the board has a majority of outside directors and negative when it does not.

${ }^{18}$ Agrawal and Knoeber (1996) find a negative relation between the percentage of outsiders on the board and firm performance. Klein (1998) finds a positive relation between the percentage of inside directors on finance and investment committees and accounting and stock market performance.
} 
which results in the board to be less involved in the management process. ${ }^{19} \mathrm{I}$ include the logarithm of the board size because its effect increases a decreasing rate.

\section{Beneficial ownership}

Blockholders have a direct incentive to monitor managers actively, which reduces managerial discretion (e.g., Grossman and Hart (1980), and Shleifer and Vishny (1986)). On the other hand, large shareholders sometimes lack incentives to monitor management due to reduced market liquidity and risk aversion and hence lead to greater levels of managerial discretion (e.g., Admati et al. (1994), Burkart et al. (1997), Kahn and Winton (1998), and Maug (1998)). Furthermore, large shareholders could also collude with management against smaller investors enhancing managerial discretion (e.g., Barclay and Holderness (1991), and Becht et al. (2003)). ${ }^{20}$ I employ the percentage of stock ownership by beneficial ownership to proxy for blockholder holdings.

\section{Director age}

Director age is likely to reflect the effectiveness of the board in monitoring the CEO where boards dominated by older directors are expected to be associated with higher levels of managerial discretion. In fact, National Association of Corporate Directors NACD (1996) Blue Ribbon Commission guidelines urge mandatory retirement ages for directors. Core et al. (1999) and Vafeas (2003) find that CEO pay rises with the number of older directors which is likely to indicate lack of board involvement.

\section{B. Measurement of financial variables and firm characteristics}

The analyses consider both book leverage and market leverage as proxies for firms' capital structure. Book leverage is defined as the ratio of book debt to total assets, and market leverage is defined as the book value of debt to the sum of the book value of

\footnotetext{
19 Jensen (1993) suggests that large boards can be less effective than small boards. Yermack (1996) documents that smaller boards are associated with higher firm values.

${ }^{20}$ Holderness (2003) concludes in his survey that few major corporate decisions have been shown to be different in the presence of a blockholder.
} 
debt and the market value of equity. ${ }^{21}$ The incremental financing activities that are studied are net equity issues, net debt issues, and changes in retained earnings. Using balance sheet items, I define net equity issues as the change in the book value of equity minus the change in retained earnings divided by total assets. Net debt issues are then defined as the change in total assets net of the change in retained earnings and net equity issues divided by total assets observed at the beginning of the period. ${ }^{22}$ । calculate retained earnings as change in retained earnings divided by total assets.

The set of firm characteristics I use as control variables include profitability (earnings before interest, taxes and depreciation), asset tangibility (net property, plant and equipment), research and development expense, selling expense, firm size (logarithm of net sales), and the market-to-book ratio. ${ }^{23}$ An indicator variable is included to differentiate observations with missing or zero R\&D expense from the rest. Selling expense and research and development expense are scaled by net sales, and the remaining capital structure proxies are scaled by total assets. I also include firms' 3-year cumulative logarithm of monthly stock returns to control for their most recent performance.

\section{Sample}

My analyses are based on data from three different sources. Data on variables associated with managerial attributes, board structure, and blockholder ownership are extracted from Compact Disclosure. ${ }^{24,25}$ The sample period spans from 1988 to 2005

\footnotetext{
${ }^{21}$ I follow Fama and French 2002 to construct the book value of debt as total assets minus book value of equity. Book equity is defined as total assets less total liabilities and preferred stock. If preferred stock has a missing value I replace it with the redemption value of preferred stock.

${ }^{22}$ The robustness tests are conducted using constructs from the cash flow statement items.

${ }^{23}$ These variables are previously considered by Titman and Wessels (1988) and Rajan and Zingales (1995).

${ }^{24}$ Disclosure database contains abstracts of the Securities and Exchange Commission filings and excerpts from the annual reports between 1988 and 2005. Appendix 1 provides a detailed description of the extraction of the governance variables from Compact Disclosure, the compilation of the rest of the sample and the construction of the variables.

${ }^{25}$ Although Compact Disclosure is the best database available on block ownership data it has some inconsistencies (see Dlugosz et al. (2006)). To address this concern, I test the robustness of the analyses using an indicator variable that takes the value one if a firm has at least one of these large investors and zero otherwise. Qualitatively, the results remain the same. I further examine the robustness of the results by using the blockholder data that is compiled by Dlugosz et al. (2006) and get similar results.
} 
including about 5,700 firm clusters (the sample is limited due to the availability of the governance data). Equity returns and price data are obtained from CRSP. I extract the financial data from Compustat, excluding firms in financial services (SIC 6000-6999) and utilities (SIC 4900-4999) as the standard capital structure and agency considerations have different implications on firms in these industries. I further restrict the sample to firms with book values of assets that are greater than $\$ 10$ million.

Table 1 Panel A displays the sample means, medians, standard deviations, and minimum and maximum values of the aforementioned variables. The table also includes sample correlations between firm characteristics and the discretion measures and firms' capital structure and financing measures (Panel B) and the correlation among the discretion proxies (Panel C).

\section{[Insert Table 1 about here]}

A quick look at the sample characteristics of the discretion measures suggest that the median firm in the sample have about 35 percent its shares held by blockholders, eight directors on the board with a median director age of about 58, a CEO who also carries a chairman title, 78 of its board seats occupied by outside directors, and a CEO who is about 54 years old.

The relatively modest correlations among the discretion proxies suggest that the proxies capture different aspects of managerial discretion. Generally, large boards seem to have more outsiders on the board. Also, older CEOs tend carry the dual CEOChairman of the board title and they tend to work with boards that are consisted of relatively older directors. The remarks on the associations between the discretion and financing characteristics are deferred to the following section as it provides a more comprehensive discussion.

\section{Managerial discretion and financing decisions}

The analysis in this section investigates the influence of managerial discretion on firms' financing decisions. I examine various specifications using net debt issues, net equity issues, and changes in retained earnings as dependent variables. The goal here is 
to inspect whether managerial discretion plays a role in determining firms' financing decisions. The regression specification takes the following form:

$$
\text { Dependent Variable } \left.i, t=\beta_{0}+\beta_{1} \text { Discretion Proxy(ies) }\right)_{i, t-1}+\beta_{2} \text { Controls }, t-1+\beta_{3} D_{i, t-1}+\varepsilon_{i, t}
$$

The regression is estimated on two sets of dependent variables. The first set considers the "net amount" of debt and equity financing, and changes in retained earnings all measured over a one year period as a percentage of total assets at the beginning of the observation period. The second set of dependent variables explicitly considers the choice between debt versus equity in issuance and repurchase decisions where a financing decision is qualified as a repurchase or an issuance decision if the net amount issued (or repurchased) is at least 5 percent or greater than the beginning period total assets. ${ }^{26}$ Using these qualifying debt and equity issuances (repurchases), I construct the debt versus equity issuance (repurchase) as net debt issued (repurchased) minus net equity issued (repurchased).

In order to address the causality problem, at least partially, all the regressors are observed at year t-1 and the dependent variable is observed at year $t$. The set of discretion proxies include the percentage of blockholder ownership, logarithm of board size, an indicator variable if the CEO is also the chairman of the board, the percentage of outside directors on the board, and the logarithm of CEO age. Control variables include measures of growth opportunities (market-to-book ratio), asset tangibility (property, plant, and equipment), uniqueness (research and development expense, an indicator variable that separates the zero values of $R \& D$, and selling expense), profitability (earnings before, interest, taxes, and depreciation), size (logarithm of sales), and recent firm performance (3-year cumulative logarithm of monthly stock returns). A one-year lagged value of the book leverage ratio is included as the preceding capital structure conditions are likely to affect the financing decisions. In addition, I include industry and year indicator variables to further eliminate potential unobserved characteristics. ${ }^{27}$

\footnotetext{
${ }^{26}$ This definition of issuance and repurchase decisions is used in several papers. See, for example, Hovakimian et al. (2001).

${ }^{27}$ I use the Fama and French (1997) industry classification. See Kenneth French's website.
} 
The coefficient estimates are constructed using standard OLS regressions. The statistical significance of the estimated coefficients is obtained through the clustering technique, which corrects for the heteroskedasticity and (time-series) serial correlation concerns in the residuals. ${ }^{28}$

\section{A. Net debt issues, net equity issues, and changes in retained earnings:}

The results are presented in Tables 2 which includes three models all of which are small modifications of the regression model expressed in Equation (1). Model 1 is the baseline case where the dependent variable is regressed on firm characteristics and the set of control variables discussed above. Model 2 is the main model where the dependent variable is regressed on all of the discretion proxies, firm characteristics, and the control variables. Model 3 is estimated as a robustness check where the dependent variable is regressed on each discretion proxy individually including other control variables (hence, each line in Model 3 is a separate regression).

\section{[Insert Table 2 about here]}

Table 2 Panel A shows that firms with high market-to-book ratios, more tangible assets, no research and development expense, and good performance tend to issue more debt. Whereas, profitable, large firms with high leverage ratios tend to issue less debt. These results are consistent with the prior literature. The results on the discretion proxies suggest these characteristics are significantly related to the amount of net debt issued. For example, large equity holding of beneficial investors are related to increased amounts of net debt issued. Boards with older directors and older CEOs tend to issue less debt. Both sets of results suggest that discretion and the amount of net debt issued are inversely related. However, firms with large boards and dual CEO and chairman titles, both of which associated with greater level of discretion, tend to issue more debt.

\footnotetext{
${ }^{28}$ Petersen (2008) recommends cluster regressions as the best approach to correct for heteroskedasticity and within [firm] cluster correlation. Bootstrapping the standard errors is an alternative way to estimate efficient standard errors and the efficiency gain is similar to the cluster regressions. I report cluster regressions because of the relative ease of the estimation procedure.
} 
Next, Table 2 Panel B, presents the effect of managerial discretion and firm characteristics on the amount of net equity issued. Results suggest that firms with high market-to-book ratios, tangible assets, high research and development expense, high debt ratios in the preceding period, and better firm performance tend to issue more equity. Large firms and firms with profitable operations, however, tend to issue less equity. Discretion proxies seem to be relevant in explaining the amount of net equity issued. Higher levels of beneficial ownership and the percentage of outsiders on the board both associated with lower levels of net equity issued. Firms with large boards and dual CEO-chairman titles tend to issue more equity. Collectively, these results suggest that managerial discretion seem to be associated with high levels of net equity issued. Boards with older directors and firms with older CEOs (associated with higher levels of discretion), however, tend to issue less equity.

Finally, Table 2 Panel $C$ presents the findings on how the change in retained earnings relate to managerial discretion and firm characteristics. Profitable and large firms, and firms with good performance, tend to have higher levels of retained earnings. High market-to-book firms and unique firms (research and development expense and selling expense), however, tend to retain less of their earnings. This finding indicates that firms with growth opportunities (identified by these two characteristics) tend to take longer to generate profits that are available for retention. Firms with tangible assets and firms with high prior period book leverage ratios also retain less of their earnings. For these firms it is likely that even though they generate enough profits, they might distribute them back to the shareholders as dividends, which reduces the amount of earnings they retain. Managerial discretion proxies do not seem to have a strong relation with change in retained earnings. Board size (negative sign) and director age (positive sign) are the only two measures that seem to have some explanatory power in explaining retained earnings when all discretion proxies are considered simultaneously (Model 2). CEO age has a significant and positive effect on the amount of earnings retained when it is used as the only discretion measure. The evidence on director age and CEO age both suggest that high managerial discretion is associated with high level of retention ratios. 
In summary, analyses on net debt issues, net equity issues, and changes in retained earnings largely suggest that when managers have more discretion, they tend to decrease the amount of net debt issued, increase the amount of net equity issued and they retain more of their internally generated cash flows. Generally, managerial discretion proxies are either associated with raising more external capital regardless of the type (e.g., board size, CEO-chairman duality, and percentage of outsiders on the board), or using internally generated capital (e.g., director age and CEO age) both resulting in enhancing resources available for investment projects. Taken together, these results seem to suggest that high-discretion managers tend to become less leveraged because they grow more by retaining more earnings, issuing more equity, and issuing less debt.

\section{B. Choice between debt versus equity:}

The results are presented in Tables 3. Panel A presents the issuance decision between debt versus equity and Panel B presents the repurchase decision between debt versus equity. Each panel includes three models similar to the analysis in the preceding section. Model 1: dependent variable is regressed on firm characteristics and the set of control variables. Model 2: the dependent variable is regressed on "all" the discretion proxies, firm characteristics, and the control variables. Model 3: the dependent variable is regressed on each discretion proxy individually, with other control variables.

[Insert Table 3 about here]

The evidence on the effect of managerial discretion on the choice between issuing debt versus issuing equity is highly revealing (Panel A). For example, firms with high levels of beneficial ownership tend to prefer debt over equity when raising capital. In addition, firms with large boards and older directors tend to prefer equity over debt when they raise capital. Firm characteristics also relate to the issuance decision in ways largely consistent with prior evidence.

The results on the repurchase decision between debt versus equity, presented in Panel $B$, suggest that the most informative characteristic is the prior years' book 
leverage ratio with a strong preference for repurchasing equity over debt when the leverage ratio is high. In the case of managerial discretion proxies, beneficial ownership, board size and director age yield statistically significant estimates. Firms with large blockholder holdings tend to prefer repurchasing equity versus debt. In addition, there seems to be strong preference for repurchasing debt over equity when directors older. Both of these proxies suggest that higher managerial discretion is associated with a preference of repurchasing debt over equity. The evidence on the board size, however, suggests that larger boards tend to prefer repurchasing equity over debt and is inconsistent with the evidence on the blockholders and director age.

In summary, these results consistently predict preference for equity over debt when firms have higher levels of managerial discretion. In the case of repurchase decisions proxies measuring higher levels of managerial discretion seem to be associated with a stronger preference for repurchasing debt over equity. One exception, board size, which predicts a preference for repurchasing equity over debt, seems to reflect the tendencies of firms with large boards to prefer outside financing (with greater emphasis on equity compared to debt) over raising capital internally.

\section{Endogeneity issues:}

While there appears to be a robust correlation between the managerial discretion proxies and firms' financing policies, the results should be interpreted with some caution. For example, high-discretion managers might engage in financing decisions which would be used for investment projects that reduces the risk profile of the firm. Operating in a lower risk environment would in turn likely to reduce managers' autonomy (i.e., the level of managerial discretion) to the extent that the reduction in risk makes it more difficult to justify their exclusivity in the decision making process due the slower pace and the lesser need for a specialized and in-depth understanding of the firm's operations and financing opportunities. Consequently, the coefficient estimates of the discretion proxies (Equation 1) are likely to be biased towards zero. 
A second source of concern could arise if managerial talent, an inherent quality of the manager, might be biasing the results to the extent that it is unaccounted for by the discretion proxies. More specifically, if more talented managers tend to have greater discretion and this is not appropriately controlled in the regression model, it is likely to generate a positive correlation between the discretion proxies and the financing variables which will be embedded in the error term. As a result, the coefficient estimates for the discretion proxies will be biased towards zero (away from zero) if the theoretical prediction suggests a negative (positive) relation between the discretion proxy and the financing variable.

To partially address some of these concerns, first, I estimate firm fixed effects on the regression model presented in Equation (1) which removes the confounding influence of potentially unobserved characteristics about the firm that affect both managerial discretion and financing decisions by "de-meaning" the explanatory regressions and thus removing the influence of firm-specific factors from both the dependent and the independent variables. This regression model is equivalent to estimating the OLS models presented in Tables 2 and 3 and including indicator variables for each of the sample firms. ${ }^{29}$

\section{[Insert Table 4 about here]}

The results reported in Table 4, indicate that including firm fixed effects in the regression model reduces the power of some of the discretion proxies in explaining firms' financing decisions but overall they remain relevant. For example, from the initial set of six, three of the discretion proxies (Five, CEO-Chair duality, CEO age) remain statistically significant in the net debt regressions and four of them (Director age, CEOChair duality) remain statistically significant in the net equity regressions. In the retained earnings regressions, beneficial ownership, which has a weak explanatory power in the pooled OLS estimation (Table 2, Panel C), predicts a decline in the amount of capital retained. In the debt-versus-equity issuance and repurchase regressions

\footnotetext{
${ }^{29}$ Note that, the fixed effects models assume that these unobserved characteristics do not change over time.
} 
beneficial ownership (Five) and board size are the only statistically significant discretion proxies for the respective models with the same signs for the coefficient estimates as in the pooled OLS regressions. The F-test on the overall relevance of the discretion proxies is statistically significant in all specifications.

It is important to note that managerial talent is likely to be time-invariant at the manager level and might not be perfectly controlled for in the firm-fixed effects regressions. Since the Compact Disclosure database does not have a unique CEO-firm identifier, I estimate manager-fixed effects regressions using the Execucomp CEO-firm identifier (co_per_rol) on the subset of the sample that is covered by this database. ${ }^{30}$ These unreported tests suggest that the statistical significant of the discretion proxies decline further on the sample of S\&P 1500 firms where beneficial ownership (net equity, change in retained earnings, debt-versus-equity regressions) and board size (debtversus-equity regression) are the remaining relevant discretion proxies in explaining the financing decisions.

Based on these robustness tests, I conclude that the correlation between managerial discretion and financing decisions is not only robust, but is also consistent with causation running from managerial discretion to financing decisions.

\section{Managerial discretion and capital structure dynamics}

In this section, I examine how managerial discretion impacts firms' capital structure dynamics. More specifically, I examine the effect of discretion on changes in debt ratios in response to firms' accumulated financing and investment activities and their tendencies to maintain a target capital structure. In this regard, this section builds on the analyses presented in the preceding section that examines in isolation the effect of discretion on firms' incremental financing decisions and managers' preferences for debt versus equity when they make issuance and repurchase decisions.

\footnotetext{
${ }^{30}$ Note that this is not the original sample since it is limited by the coverage of Execucomp database which contains information S\&P 1500 firms between 1992 and 2005.
} 
Since the focus is on the effect of accumulated activities on capital structure, similar to Kayhan and Titman (2007), I examine changes in capital structure over a three-year period. This long horizon framework allows me to isolate managers' deliberate financing decisions from random fluctuations in the debt ratio. The empirical methodology follows a two step procedure to estimate the determinants of the changes in the debt ratio and is closely related to the partial adjustment models that have been previously examined in the literature. ${ }^{31}$ In the first step I construct a proxy for the target leverage ratio as the predicted value from a regression of debt ratios on tradeoff variables that are discussed earlier. ${ }^{32}$ Then, in the second step, I estimate the following regression:

$$
\Delta D_{i,[t, t-3]}=\beta_{0}+\beta_{1} \text { Financing History } i,[t, t-3]+\beta_{2}\left(D_{i, t-3}-D_{i, t-3}^{T}\right)+\varepsilon_{i, t}
$$

$\Delta D_{i,[t, t-3]}$ is the change in the debt ratio between year $\mathrm{t}\left(D_{i, t}\right)$ and year t-3 $\left(D_{i, t-3}\right)$. Financing History $i,[t, t-3]$ is a set of variables that measure firms' financing, investment, and stock price histories constructed over a 3-year window (year $\mathrm{t}$ and year $\mathrm{t}-3$ ). $D_{i, t-3}-$ $D_{i, t-3}^{T}$ (leverage deficit) is defined as the difference between the observed leverage ratio $\left(D_{i, t-3}\right)$ and the target proxy $\left(D_{i, t-3}^{T}\right.$, constructed in the first stage) measured at the beginning of the 3-year window (year t-3).

To estimate the effect of managerial discretion on the debt ratio dynamics as summarized in Equation (2), I employ an endogenous switching regression model with unknown sample separation, which allows me to estimate Equation (2) separately for high-discretion and low-discretion regimes. While the implementation of this technique requires assuming two regimes is sufficient to classify managers into different discretion groups, the points of structural change are not observable and are estimated together with the leverage regression for each discretion regime. In addition, the selection into

\footnotetext{
${ }^{31}$ For partial adjustment models see, for example, Jalilvand and Harris (1984), Auerbach (1985), ShyamSunder and Myers (1999), Hovakimian et al. (2001), and Kayhan and Titman (2007). The alternative method would be to use the target proxies directly in the regression rather than using the predicted target leverage that is estimated from these proxies that potentially reduces the sampling error due to imputed regressors. Both techniques yield similar results.

32 The regression results estimated for the construction of the target leverage proxy are presented in Appendix 2.
} 
the two regimes is done using unknown sample separation (managerial discretion is a latent characteristic and not observed directly) based on observed proxies that determine managers' propensity to be in either discretion regimes. ${ }^{33}$

\section{A. Endogenous switching regression model with unknown sample separation:}

The regression model is composed of the following three equations (estimated simultaneously): one for the selection equation, which endogenously identifies whether the observation belongs to a high-discretion or a low-discretion regime, and the remaining two for the structural equation as presented in Equation (2). The selection equation is specified as:

$$
\text { Managerial Discretion }_{i, t-3}{ }^{*}=Z_{i, t-3} \gamma+u_{i, t-3}
$$

where Managerial Discretion ${ }^{*}$ is the latent characteristic that measures the ability of managers to pursue their own objectives, considered to be determined by blockholder ownership, board size, director age, CEO-chairman duality, board independence, and CEO age, all observed in year t-3 which corresponds to the beginning of the 3-year observation period for the variables in the structural equation. ${ }^{34}$

The model uses this latent characteristic to separate the two regimes such that observations with Managerial Discretion ${ }^{*} \geq 0$ (i.e., $u_{i, t-3} \geq-Z_{i, t-3} \gamma$ ) is defined to belong to the high-discretion regime and those with Managerial Discretion ${ }^{*}<0$ (i.e., $\mathrm{u}_{i, t-3}<-Z_{i, t-3} \mathrm{Y}$ ) fall into the low-discretion regime. ${ }^{35}$ The two discretion regimes are defined as follows:

High-discretion regime:

$$
\Delta D_{i,[t, t-3]}=\beta_{0}{ }^{H D}+\beta_{1}{ }^{H D} \text { Financing History }{ }_{i,[t, t-3]}+\beta_{2}{ }^{H D}\left(D_{i, t-3}-D_{i, t-3}^{T}\right)+\varepsilon_{i, t}{ }^{H D} \text { when } \mathrm{u}_{i, t-3} \geq-Z_{i, t-3} Y(4)
$$

\footnotetext{
${ }^{33}$ See Maddala (1986) for a detailed discussion. For an application of this model in financial economics see, for example, Hu and Schiantarelli (1998) and Almeida and Campello (2007).

34 The discretion proxies are observed in year t-3 to avoid causality concerns as the variables in the structural equation are observed over a 3-year window. Choosing year $t$ as the observation period for the discretion proxies slightly improves the statistical significance of their coefficient estimates in the selection equation, but, it does not have a material impact on the estimates in the structural equation.

${ }^{35}$ The likelihood function which is used to estimate the system is briefly summarized in Appendix 3.
} 
Low-discretion regime:

$$
\Delta D_{i,[t, t-3]}=\beta_{0}{ }^{L D}+\beta_{1}{ }^{L D} \text { Financing History }{ }_{i,[t, t-3]}+\beta_{2}{ }^{L D}\left(D_{i, t-3}-D^{T} i, t-3\right)+\varepsilon_{i, t}{ }^{L D} \text { when } u_{i, t-3}<-Z_{i, t-3} \gamma
$$

This three equation system is estimated simultaneously using the Maximum Likelihood method where the differential capital structure dynamics across firms in high- and low discretion regimes are captured by the differences between $\beta^{H D}$ and $\beta^{L D}$. Following previous applications, the error terms in the structural equations $\left(\varepsilon^{H D}\right.$ and $\left.\varepsilon^{H D}\right)$ and the selection equation (u) are assumed to be jointly normally distributed with a covariance matrix that normalizes the variance of the residual of the selection equation to 1 and allows for nonzero correlation between the shocks to capital structure changes and the shocks to managerial discretion. ${ }^{36}$ This nonzero covariance matrix makes the model I use an endogenous switching regression model.

The statistical significance of the estimated coefficients is obtained through the clustering technique, which corrects for the heteroskedasticity and (time-series) serial correlation concerns in the residuals. The hypothesis tests on the statistical significance of difference between the two regimes are conducted on each parameter estimate using a Wald test and reported along with the estimation results.

Note that, while this system yields two distinct estimates for the extent to which capital structure changes differ across the regimes along with the estimates for the likelihood that firms are assigned to either regime (all of which are simultaneously determined), it does not automatically tell which regime is the high-discretion regime. For identification, I need to use my theoretical priors about how discretion proxies are associated with managerial discretion (i.e., the signs of the coefficient estimates). ${ }^{37}$ As I show in the results section, the data yields an unambiguous regime assignment.

The clear advantage of this approach is that it allows me to use multiple proxies to predict whether firms have high- or low-discretion managers. This is in contrast to the traditional method of splitting the sample according to a priori characteristics and using

\footnotetext{
${ }^{36}$ See Maddala (1986) and Hu and Schiantarelli (1998) for details.

${ }^{37}$ For such identification strategies within the context of unknown sample selection models see Maddala (1986) and Almeida and Campello (2007).
} 
them one at a time. An added advantage of the estimation of the selection equation is that it produces statistics to test the significance of a given factor assumed to proxy for discretion, while controlling for the information contained in other factors. It should be noted that the identification of the proxies used in the selection equation is an important factor in the success of the regime separation. While the initial set of six proxies captures a comprehensive set of attributes, in Section 4, I discuss a set of robustness tests that incorporate additional variables.

In the following paragraphs, I first discuss the determinants of changes in debt ratios that include proxies for the firms' financing histories and the distance between their observed leverages and target capital structures. Then I present the results.

\section{B. Determinants of changes in debt ratios:}

\section{Accumulated total external financing:}

The measure for the total external financing is the sum of net equity issues and net debt issues. This measure (generally referred to as the Financial Deficit (FD)), can be represented as an accounting identity that measures the difference between firms' investment needs and their internally generated cash flows, and has been previously used to test the pecking order argument. ${ }^{38}$ Specifically, a firm's total external financing over a year is represented as:

$$
\mathrm{FD}=\Delta \mathrm{e}+\Delta \mathrm{d}
$$

When firms' investment expenditures outrun their internally generated cash flows the financial deficit will take positive values, whereas when firms are highly profitable and have limited investments this variable will be negative.

Pecking order hypothesis suggests that firms would avoid equity financing when they do not have enough cash flows to cover their investment needs. Thus, when firms have external financing needs, they prefer debt capital to equity capital, leading to an increase in their leverage ratios. However, the pecking order prediction for the

\footnotetext{
${ }^{38}$ Shyam-Sunder and Myers (1999), Frank and Goyal (2003), and Kayhan and Titman (2007).
} 
relationship between financial deficit and leverage ratio may be very different when one considers managers' discretion over financing decisions. When managers have discretion they may limit the use of debt when they have external capital needs in order to reduce the performance pressure or to protect their human capital; thus, the relationship between the leverage ratio and the financial deficit would be weaker than the standard pecking order prediction. On the other hand, using equity to fund the financial deficit may adversely affect the managements' power since equity financing reduces the fraction of votes controlled by the management. Therefore, high-discretion managers, who want to make large investments relative to their internally generated funds, may take on additional debt to convince outside investors that their investment decisions make sense. If this is the case, the relationship between financial deficit and leverage ratio will be strong and the changes in the leverage ratio as a result of high financial deficit may have long lasting effects.

To take into account the possibility that managerial discretion may generate differences in managers' tendencies for repurchase decisions; I examine the effect of accumulated external financing on changes in debt ratio separately for the negative and the positive values of the financial deficit.

\section{External financing based on market conditions:}

The objective here is to measure the external financing that is motivated by firms' stock price performance, known as market timing. This argument suggests that firms that raise external capital when their stock prices are high are likely to use more equity than firms that raise external capital when their stock prices are low. Given this, firms are expected to have lower debt ratios if they happen to raise capital when their stock prices are high and higher debt ratios if they happen to raise capital when their stock prices are low.

Past literature generally explain firms' tendency to time the market with the "irrational investors" argument that suggests that rational managers take advantage of investor exuberance by issuing equity when (they believe) their stock price is 
overvalued. This paper presents an alternative explanation whereby managers with more discretion in their financing choices and the desire to achieve lower debt ratios issue equity after superior stock price performance.

Following Kayhan and Titman (2007), I implement two timing variables that are functions of the amount of the total capital raised (i.e., financial deficit) and the marketto-book ratio.

$$
\begin{aligned}
\text { Yearly Timing (YT) } & =\left(\sum_{s=0}^{t-1} F D_{s} *(M / B)_{s} / t\right)-\overline{F D} * \overline{M / B} \\
& =\operatorname{côv}(F D, M / B) \\
\text { Long-Term Timing (LT) } & =\left(\sum_{s=0}^{t-1}(M / B)_{s} / t\right) *\left(\sum_{s=0}^{t-1} F D_{s} / t\right) \\
& =\overline{M / B} * \overline{F D}
\end{aligned}
$$

where the summations are taken for each firm-year observation over a five year period.

The first measure, which is referred to as the yearly timing $(Y T)$, is the sample covariance between total external financing and the market-to-book ratio. It measures how firms' external financing and their market-to-book ratios co-vary over time. The long-term timing measure $(L T)$ allows testing whether managers act as though their costs of equity financing is inversely related to the market to book ratio (which some would argue is consistent with empirical observations). If this is the case, the pecking order is reversed for firms with high market to book ratios.

\section{Accumulated stock returns:}

To examine the direct effect of stock price changes on the debt ratio I include firms' stock returns ( $r$ ), measured as the cumulative log return on the stock over the previous five years. If high-discretion managers choose not to rebalance their debt ratios following periods of increasing stock prices, partly due to their preference for lower leverage, stock returns will be negatively associated with debt ratios (measured with the

market value of equity) (Welch (2004)). Furthermore, if managers with discretion are more likely to issue equity when they experience relatively high market valuations 
relative to the ones who cannot act on their self-interests, stock returns will be negatively related to the book leverage.

\section{Leverage Deficit:}

If firms have the tendency to move towards their target debt ratios, then firms that have leverage ratios lower (higher) than their targets are likely to experience future increases (decreases) in their debt ratios. ${ }^{39}$ I define leverage deficit as the difference between a firm's target leverage and its realized level. ${ }^{40}$ In order to account for the asymmetry in leverage increasing and leverage decreasing adjustments I split the leverage deficit into two components: positive leverage deficit (leverage ratio is higher than the target leverage) and negative leverage deficit (leverage ratio is lower than the target leverage).

When one considers managerial discretion it is quite likely that managers' preferences for lower leverage ratios may slow down the extent to which firms' move towards their target debt ratios. Specifically, managers who achieve low leverage ratios as a result of increases in their stock prices, or due to their market timing activities may prefer not to undo the changes in their capital structure.

Including a leverage deficit into the analysis also addresses the potential endogeneity problem of the financial deficit. For example, firms that are temporarily over-leveraged may cut back their investment expenditures in order to reduce their financial deficits or equivalently increase the free cash flow available to pay down their debt. This can induce a positive relation between the financial deficit and changes in the leverage ratio for reasons that have nothing to do with the pecking order theory.

\footnotetext{
${ }^{39}$ There is a potential asymmetry in the leverage increasing and leverage decreasing adjustments because of wealth transfers from equity holders to debt holders that keep firms from paying down their debt (Myers (1977)), or information asymmetries that make it more difficult to issue equity.

${ }^{40}$ The proxy for the target debt ratio is the predicted value from a Tobit regression of observed debt ratios on variables that have been discussed as the control variables in the previous section. This estimation technique allows restricting the predicted value of the leverage ratio between 0 and 1 . The regression results for the first stage regression are reported in Appendix 2.
} 


\section{Results:}

Results are reported in Table 5 for the switching regression model (Equations (3)(5)). Panels $A$ and $B$ contain the results for changes in book leverage and market leverage, respectively. In each panel, the first row reports the results for the selection equation and the following two rows report the results for the structural equation. The last row in each panel reports the $P$-values for the difference in the coefficient estimates between the two regimes. In addition, at the top of each panel $P$-values are reported for the test of the null hypothesis that a single discretion regime instead of two regimes (high- and low-discretion), is sufficient to describe the data. These two tests are based on a Wald test and a Likelihood Ratio test, respectively, for which the $\chi^{2}$ distribution is used for statistical inferences. The economic significance of the results for both the selection equation and the structural equation are presented in Table 6 separately for book and market leverage regressions (Panels $\mathrm{A}$ and $\mathrm{B}$ ). For the selection equation, I present the percentage change in the predicted propensity of being in the highdiscretion regime due to a one standard deviation increase in the discretion proxy where the values of the variables in the base case are set equal to their sample mean. For the structural equation, I present the percentage change in leverage ratio due to a one standard deviation increase in the right hand side variable.

The estimates for the switching regression in Table 5 support the identification of the two discretion regimes. The results suggest that, larger boards, older directors, fewer outsiders on the board, older CEOs enhance to the propensity of facing a highdiscretion regime and are consistent with the theoretical priors. The remaining two discretion proxies, beneficial ownership and CEO-chairman duality have statistically insignificant selection power in both leverage specifications. In terms of determining managers' propensity for having discretion, board size, director age, and outsiders on the board have about the same economic relevance; a one standard deviation increase in board size and director age and one standard deviation decrease in the outsiders on the board leads to an approximately 9 percent increase the probability of being in high- 
discretion regime (Table 6, Panel A).$^{41}$ CEO age, also has a relatively significant predictive power, a one standard deviation change in CEO age increases the propensity of being in high-discretion regime by 7.47 percent. The corresponding figures for board size, director age, outside director, and CEO age in the market leverage regressions are $18.67 \%, 17.69 \%, 14.17 \%$, and $12 \%$, respectively (Table 6, Panel B).

\section{[Insert Tables 5 and 6 about here]}

The estimates for the structural equation presented in Table 5 are consistent with the idea that managerial discretion is an important factor in explaining how firms' capital structures change over time in response to their financing, investment, and stock price histories. In the book leverage regressions, the coefficient estimates on the positive financial deficit are much larger in the high-discretion regime than in the lowdiscretion regime $(0.188$ versus .042$)$, indicating that the high-discretion firms are more sensitive to the pecking order considerations. The economic significance of this differential effect, reported in Table 6, translates into a 10.4 percent larger increase in book leverage in the high-discretion regime in response a one standard deviation increase in positive financial deficit and is statistically different from zero with a $P$-value of 0.000 . In the case of negative financial deficit, which indicates that the firm has a financing surplus, the decline in book leverage due to a one standard deviation increase in negative financial deficit is about a 3.4 percent larger in the high-discretion regime compared to that of low-discretion regime and the difference is statistically significant. The results in the market leverage regression are very similar.

Yearly timing effect on leverage is highly influenced by managerial discretion and results are robust in both book and market leverage regressions. While there is weak yearly timing effect on capital structure for firms with low discretion managers, in the high-discretion regime the decrease in leverage as a result of yearly timing is about three times larger compared to one observed in the low-discretion regime. The results

\footnotetext{
${ }^{41}$ The sample standard deviations of the discretion proxies are .28 (Five), .40 (Board size), .12 (Director age), .49 (CEO-Chair duality), .18 (Outsiders on the board), and .16 (CEO age). In calculating the percentage change in the probability of being in high-discretion regime in response to a one standard deviation change in the discretion proxy, I set the values of all variables in the base case equal to their sample mean values. Using median values do not have a material impact on the calculation.
} 
on the long-term timing are somewhat similar to those of yearly timing measure. The decline in book leverage due a one standard deviation change in LT is 4.4 percent larger in the high-discretion regime compared to the one in the low discretion regime (Table 6 Panel A). These results indicate that managers with more discretion in their financing choices, who desire to achieve lower debt ratios, tend to issue equity after favorable stock price performance. This systematic activity leads to lower leverage ratios for the group of firms that have high-discretion managers.

Note that in the market leverage regressions, the sensitivity of changes in debt ratio to long-term timing seem to be marginally higher in the low-discretion regime (a 3.75 percent decrease in low-discretion regime compared to a 3.57 percent decrease in highdiscretion regime). Considering that the long-term timing measure is the interaction of financial deficit and market-to-book ratio, this evidence indicates that the reversal of the pecking order effect for firms with high average market-to-book ratios is smaller for managers with high-discretion than for the ones with low-discretion. This evidence may suggest that, unlike their low-discretion counterparts, managers with high-discretion do not necessarily finance their growth opportunities with less debt. Or it could be that high-discretion managers tend to work for firms that do not have very good investment opportunities; hence, consideration of financing growth opportunities with equity does not become an issue. ${ }^{42}$

The effect of cumulative stock returns on changes in debt ratio is strongly negative in both the book and market leverage regressions for both low- and high-discretion regimes. When measured in market values, the decline in leverage due to cumulative stock returns is about 50 percent larger in the high-discretion regime than in the low discretion regime (12 percent versus 18.6 percent). When measured in book values, however, the decline in leverage is 5.6 percent in the low-discretion regime and 3.2 percent in the high-discretion regime. The evidence in the market leverage regressions suggest that high-discretion managers are more willing to let their debt ratios decline following periods of increasing stock prices by failing to rebalance their debt ratios. The

\footnotetext{
${ }^{42}$ Indeed, in unreported analysis, when market-to-book ratio is included in the selection equation, the sign of its coefficient estimate is consistent with lower discretion.
} 
evidence in book leverage regressions partly reflect that, for high-discretion firms the effect of the appreciation in stock prices on changes in debt ratio does presents itself more through managers' active market timing actions captured by the yearly timing and long-term timing measures than their passive reluctance to rebalance their debt ratios.

Finally, there is strong evidence that firms tend to rebalance their capital structures over time regardless of the level of managerial discretion. However, the speed at which firms move towards their capital structure is much lower in the high-discretion regime. Furthermore, the asymmetry between the leverage increasing and leverage decreasing adjustments towards a target ratio seem to be less relevant for this high-discretion regime.

\section{Robustness}

In this section I discuss several analyses on the robustness of the selection equation in predicting the likelihood of being in one of the two discretion regimes and the robustness of the structural equation in estimating the determinants of the capital structure dynamics in these regimes.

\section{A. Controlling for firm characteristics in the selection equation:}

Some of the firm characteristics, particularly the firm size, are likely to be highly correlated with some of the discretion proxies (e.g., board size) and to the extent that these firm characteristics are correlated with the latent managerial discretion characteristic, the coefficient estimates in the selection equation could be biased. For robustness, I estimate the selection and the structural equations presented in Section 3 by including firm characteristics presented earlier. After this modification, the selection equation takes the following form:

$$
\text { Managerial Discretion }_{i, t-3}{ }^{*}=Z_{i, t-3} \gamma+\text { Firm characteristics }{ }_{i, t-3} \delta+u_{i, t-3}
$$

where $Z_{i, t-3}$ is the vector for discretion proxies (Five, Board size, Director age, CEO-Chair duality, Outsiders on the board, and CEO age) and Firm characteristics are market-to- 
book, property, plant and equipment, $R \& D$ expense, $R \& D$ indicator variable, selling expense, EBITDA, and firm size, all observed in year $t-3 .{ }^{43}$ The structural equation remains same as presented in Equations 4 and 5.

Unreported results suggest that including firm characteristics to the selection equation do not have a material impact on both the selection and the structural equation coefficient estimates. In the selection equation, similar to the results presented in Section 3, the strongest predictors for the propensity of being in the lowor high-discretion regime are Board size, Director age, outside directors, and CEO age. In terms of economic significance, the percentage change in the predictive power of the discretion proxies decline about 50 percent in the book leverage regressions. For example, a one standard deviation increase in the outside director variable increases the propensity of being in high-discretion regime by 4.47 percent. In the structural equations, the difference in the coefficient estimates across low-and high-discretion regimes remain almost identical.

\section{B. Controlling for antitakeover provisions in the selection equation:}

Antitakeover provisions have recently become a popular proxy for CEO power. To the test if this characteristic provides any additional benefit in identifying the low- and high-discretion regimes, I implement the regression model in Section 3 by including this variable to the selection equation. Similar to the previous robustness test, the regression model stays intact except the inclusion of the new variable to the selection equation.

For measurement, I use the Governance index (G-index), introduced by Gompers et al. (2003), which is based on the 24 anti-takeover provisions included in the survey conducted by the Investor Responsibility Research Center (IRRC). ${ }^{44}$ This index is

\footnotetext{
${ }^{43}$ The three-year cumulative return variable is excluded from the selection equation since this variable is a part of the structural equation. Including this variable to the selection equation reduces the statistical significance but the results remain qualitatively the same.

${ }^{44}$ Bebchuk et al. (2004) construct a similar index (E-index) using only 6 of the 24 provisions arguing that the remaining provisions are not as relevant hence excluding them reduces the noise in the measure. Bebchuk and Cohen (2005) suggest that the existence of staggered boards (one of these 24 provisions), which prevents shareholders from replacing a majority of the board of directors without the passage of at
} 
intended to summarize the balance of power between shareholders and managers from the perspective of anti-takeover provisions (such as delaying a hostile takeover bid, officer protection, voting rights, state laws, and other defenses) on an integer scale from zero to twenty-four; zero being the least powerful CEO and twenty-four being the most powerful CEO. G-index is available only for firms included in the S\&P 1500 index and for years the survey is conducted $(1990,1993,1995,1998$, and every two years after that until 2006). For the years between surveys, I assume that the index score is the same as in the previous survey year. Note that including the G-index variable to the selection equation reduces the number of observations from about 25,696 to 4,221 and firm clusters from 4,862 to 1,115 .

\section{[Insert Table 7 about here]}

Results, presented in Table 7, are generally similar to the ones presented in Tables 5 and 6: compared to low-discretion managers, high-discretion types tend to have greater increases their debt ratios in response to external financing needs (positive financial deficit) and larger decreases their debt ratios in response to financing surplus (negative financial deficit), market timing activities and appreciation in their stock prices. In addition, high-discretion managers are slower in rebalancing their debt ratios towards their targets, though they are still concerned about maintaining a target capital structure, consistent with our earlier findings.

The selection model produces statistically significant estimate for G-Index with a sign that is consistent with the signs of the other discretion proxies in the model where higher levels of G-index is associated with greater managerial discretion. For example, in the book leverage regressions, firms with larger boards, older directors, and higher Gindex values are selected into high-discretion regime. In market leverage regressions, the identification of the regime is based on board size and G-index. The estimate for the outside directors is only marginally significant in both book and market leverage

least two annual elections and make it harder to gain control of a company in either a stand-alone proxy contest or a hostile takeover, provides the most significant enhancement in CEO power. I test the robustness of these alternative utilizations of the antitakeover provisions. The results are largely the same but the G-Index and the staggered board indicator have relatively higher statistical significance in identifying managerial discretion. 
regressions. In quantitative terms, a one standard deviation increase in board size increases the probability of being in the high-discretion regime by a 13.79 percent. The corresponding figures for Director age and G-index are 7.06 percent and 9.01 percent.

\section{Controlling for managerial incentives:}

One could argue that in addition to the proxies of managerial attributes and corporate governance characteristics that have I introduced to measure managerial discretion, managerial incentives might play a role in the way debt ratios respond to their investment, cash flow and stock price histories and their tendencies to maintain a target capital structure. To test the robustness of the evidence presented in Section 3, I estimate the leverage change regressions (Equations 4 and 5) with two additional variables included in the selection equation (Equation 3), CEO option holdings and CEO stock holdings, to proxy for the extent to which managers' interests are aligned with those of shareholders in maximizing firm value. In terms of the estimation procedure the only modification is made to Equation 3 which characterizes the latent Managerial Discretion measure. The specifications in Equation 4 and Equation 5 remain intact.

The two new incentive variables are compiled from the Execucomp database which covers the managerial characteristics and compensation of firms that have been in the S\&P 1500 list anytime between 1992 and 2005. CEO stock option holdings are measured as a percentage of total shares outstanding to proxy for performance-based incentive compensation. I expect managers to be highly entrenched when their compensation is not very sensitive to their performance, i.e., managerial entrenchment is lower for higher levels of option holdings. ${ }^{45}$ CEO stock ownership could be considered to proxy for both managerial ability and incentives. CEOs with higher ownership stakes may have greater incentives to make value maximizing decisions than their counterparts, reflecting their lower entrenchment levels. However, these incentives may reverse if high ownership insulates managers from disciplinary mechanisms (e.g., Morck et al. (1988), and McConnell and Servaes (1990)), resulting in higher

\footnotetext{
${ }^{45}$ Hall and Liebman (1998) show the strong relation between firm performance and CEO compensation is attributable to changes in the value of CEO stock option holdings.
} 
entrenchment levels. ${ }^{46}$ It is not clear where this entrenchment effect kicks in, but based on the findings of Morck et al. (1988), I define CEO stock holdings as equal their percentage ownership if it is greater than or equal to $5 \%$ of the outstanding shares for the company and zero otherwise to proxy for the entrenchment feature of CEO ownership. ${ }^{47}$ Since the sample coverage for the discretion variables between and the Gindex are very similar, I present results using the most comprehensive set of proxies. Note that, inclusion of these characteristic to the current set of discretion characteristics impose restrictions on the heterogeneity of the sample firms and the sample period (the number of observations decline to about 3,659 and the number of firm clusters decline to about 973).

\section{[Insert Table 8 about here]}

Table 8 presents the results. Overall, results are consistent with the earlier evidence discussed in Section 3 (Table 5) in that the effect of financial deficits, yearly and longterm timing variables, and cumulative stock returns on the changes in debt ratios is greater when managers have discretion. Furthermore, consistent with earlier findings, high-discretion managers are slower in rebalancing their debt ratios towards their targets, though they are still concerned about maintaining a target capital structure.

The selection model produces statistically significant and consistent signs for the coefficient estimates for board size and G-index in determining the selection between low- and high-discretion regimes. The signs for the coefficient estimates for Director age and outside director are also consistent in predicting the propensity of being in the high discretion regime but their statistical significance is relatively marginal. The two discretion proxies, however, do not seem to provide additional benefit to the identification of managerial discretion.

\footnotetext{
${ }^{46}$ Jensen (1986) explains how managers use their effective control rights to pursue projects that benefit then rather than investors. Grossman and Hart (1988) describe these benefits as the private benefits of control.

${ }^{47} \mathrm{~A}$ similar approach is taken in Hadlock (1998). I also experiment with other possible choices for the cutoff point for percentage of managerial stock ownership as well as quadratic specification and generally get similar results.
} 


\section{Conclusion}

The influence of managerial incentives and discretion on capital structure has attracted considerable attention. This paper takes the view that firms' capital structure policies are the results of managers' decisions rather than considering them as solutions to the free cash flow problem. By empirically examining the role of managerial discretion on financing decisions and the capital structure changes, I shed some light on how firms with high-discretion managers become less levered. The results support the view that managerial discretion has substantial influence on firms' financing decisions, and that the change in firms' capital structures in response to firms' financing needs, stock price histories, financing activities following favorable market valuations, and their tendencies to maintain a target capital structure vary significantly due to managerial discretion.

The analyses of financing decisions show that issuance regressions consistently predict preference for equity over debt when firms have higher levels of managerial discretion. In the case of repurchase decisions, proxies measuring higher levels of managerial discretion seem to be associated with a stronger preference for repurchasing debt over equity but the evidence is somewhat mixed.

The analyses of capital structure dynamics indicate that changes in leverage ratios in response to positive and negative financial deficits is greater when managers have greater levels of discretion. This evidence supports the view that pecking order considerations have a bigger impact on debt ratios for the high-discretion regime. Furthermore, results suggest that debt changes are more sensitive to issuance activities than repurchase activities when managers have high-discretion, consistent with the findings on financing decisions.

The market timing effect on leverage is highly influenced by managerial discretion. For example, in the high-discretion regime the decrease in leverage as a result of yearly timing is about three times larger compared to one observed in the low-discretion regime. The results on the long-term timing are similar in the book leverage regressions. In the market leverage regressions, however, the sensitivity of changes in debt ratio to long-term timing seem to be marginally higher in the low-discretion regime 
compared to the low-discretion regime. This finding may suggest that, unlike their lowdiscretion counterparts, managers with high-discretion do not necessarily finance their growth opportunities with less debt. Or it could be that high-discretion managers tend to work for firms that do not have very good investment opportunities; hence, consideration of financing growth opportunities with equity does not become an issue. On the whole, the evidence on the timing variables shows that the decline in debt ratios due to a systematic issuance activity following favorable stock price performances is much larger when managers have high-discretion - consistent with their desire to achieve low debt ratios.

Cumulative stock returns have a strong negative effect on changes in debt ratio in both the book and market leverage regressions for both low- and high-discretion regimes. When measured in market values, the decline in leverage due to cumulative stock returns is about 50 percent larger in the high-discretion regime than in the low discretion regime which is consistent with the idea that high-discretion managers are more willing to let their debt ratios decline following periods of increasing stock prices by failing to rebalance their debt ratios. When measured in book values, however, the decline in leverage is higher in the low-discretion regime than it is in the high-discretion regime which could partly reflect that, for high-discretion firms the effect of the appreciation in stock prices on changes in debt ratio does presents itself more through active equity market timing actions captured by the yearly timing and long-term timing measures than passive reluctance to rebalance their debt ratios.

Finally, there is strong evidence that firms tend to rebalance their capital structures over time regardless of the level of managerial discretion. However, the speed at which firms move towards their capital structure is much lower in the high-discretion regime. Furthermore, the asymmetry between the leverage increasing and leverage decreasing adjustments towards a target ratio seem to be less relevant for this high-discretion regime.

On the methodological side, the implementation of an endogenous switching model in examining the effect of managerial discretion on capital structure changes addresses 
a major identification problem in the corporate governance literature. First, the model allows me to take into account the multiple dimensions of the managerial discretion characteristic without relying on an ad hoc summary variable. In addition, in contrast to the traditional method of splitting the sample according to a priori characteristics and using them one at a time, the model allows me to use multiple proxies to predict whether firms have high- or low-discretion managers, taking into account that the residuals in the selection of low- and high-discretion managers could be correlated with the residuals in the debt ratio regressions. These methodological improvements can provide guidance in addressing the identification problems that are pervasive in corporate finance research.

Future research can examine how the interaction between discretion and capital structure affects investment choices. High-discretion managers may make these financing decisions to achieve lower debt ratios or to invest beyond their firms' growth potential. Research has provided considerable evidence linking overinvestment problems to managerial incentives. Therefore, it is interesting to consider the other possibility and see whether managers with discretion make these financing decisions to reduce their risks, or to build empires for themselves. 


\section{Appendix 1: Variable Construction}

The following is the definition, source and construction of the capital structure and discretion variables. Change in retained earnings, net equity issues, and net debt issues are scaled by the beginning period assets.

Variable Name Variable definition

\section{Data Source Data Item}

Financial characteristics

\begin{tabular}{|c|c|c|c|}
\hline Book equity & $\begin{array}{l}\text { Total Assets - [Total Liabilities + Preferred } \\
\text { Stock] + Deferred Taxes }\end{array}$ & Compustat & $6-[181+10]+35$ \\
\hline Book debt & Total Assets - Book Equity & Compustat & 6 - Book Equity \\
\hline Market equity & Common Shares Outstanding * Price & Compustat & $25 * 199$ \\
\hline Book leverage & Book Debt / Total Assets & Compustat & \\
\hline Market leverage & $\begin{array}{l}\text { Book Debt / (Total Assets - Book Equity + } \\
\text { Market Equity) }\end{array}$ & Compustat & \\
\hline $\begin{array}{l}\text { Change in retained } \\
\text { earnings }(\triangle R E / A)\end{array}$ & $\Delta$ Retained Earnings / Total Assets & Compustat & $\Delta 36 / 6$ \\
\hline Net equity Issues (e/A) & $\begin{array}{l}\text { ( } \Delta \text { Book Equity }-\Delta \text { Retained Earnings) / Total } \\
\text { Assets }\end{array}$ & Compustat & $(\Delta$ Book Equity $-\Delta 36) / 6$ \\
\hline Net debt Issues (d/A) & $\begin{array}{l}\text { ( } \Delta \text { Total Assets / Total Assets })-(\mathrm{e} / \mathrm{A})- \\
(\Delta \text { Retained Earnings / Total Assets) }\end{array}$ & Compustat & $(\Delta 6 / 6)-(\mathrm{e} / \mathrm{A})-(\Delta 36 / 6)$ \\
\hline
\end{tabular}

Firm characteristics

\begin{tabular}{|c|c|c|c|}
\hline Market /Book & $\begin{array}{l}\text { (Total assets - Book Equity + Market } \\
\text { Equity)/Total Assets }\end{array}$ & Compustat & \\
\hline Prop., plant, and equip. & Net property, plant and equipment/Total assets & Compustat & $8 / 6$ \\
\hline$R \& D$ & Research and Development Expense/Sales & Compustat & $46 / 12$ \\
\hline R\&D indicator & $=1$ if $R \& D=0 ; 0$ otherwise & Compustat & \\
\hline Selling expense & Selling Expense/Sales & Compustat & $189 / 12$ \\
\hline EBITDA & $\begin{array}{l}\text { Earnings before interest, taxes and } \\
\text { depreciation / Total Assets }\end{array}$ & Compustat & $13 / 6$ \\
\hline Size & Ln (sales) & Compustat & $\operatorname{Ln}(12)$ \\
\hline 3-year cum. return & $\begin{array}{l}\text { Sum of the natural logarithm of monthly } \\
\text { returns }\end{array}$ & CRSP & RET \\
\hline \multicolumn{4}{|c|}{ Managerial discretion proxies } \\
\hline Five & $\begin{array}{l}\text { Holdings of } 5 \% \text { (beneficial) investors/shares } \\
\text { outstanding }\end{array}$ & Compact D & Ownership files \\
\hline Board size & Ln (board size) & Compact D & Director files \\
\hline Director age & Ln (median director age) & Compact D & Director files \\
\hline CEO-Chair duality & $=1$ if $\mathrm{CEO}$ is chairman; 0 otherwise & Compact D & Officer files \\
\hline Outsiders on the board & Number of outsiders on the board / board size & Compact D & Director files \\
\hline CEO age & Ln (CEO age) & Compact D & Officer files \\
\hline
\end{tabular}

\section{A. Compact disclosure:}

Compact Disclosure stores company data regarding the company's filings with SEC (10-K, 20-F, 10-Q, 8-K, Proxy Statement, Registration Statement, Annual Reports to Shareholders, Williams Act Filings, etc.) on CD-ROMs on monthly basis. The data is made available for the 1988 and 2005 period. The appropriate 
month for the year is chosen based on the company's fiscal year end and proxy filing date. For example, International Business Machines' fiscal year end is December $31^{\text {st }}$ and its proxy is filed in March. The monthly file chosen from Compact Disclosure is going to be March.

Next, I match Compact Disclosure and CRSP database that includes the historical CUSIP numbers. The match is first based on the last six digits of the historical CUSIP number that is disclosed in both databases (in Compact Disclosure the name of the entry is "CUSIP NO" and it is formatted as CU). A second and third round of cross-checks for the matching procedure is done by confirming the match between the ticker symbol and company name in the two databases. The resulting sample is later merged with Execucomp using GVKEY and with CRSP using PERMNO.

Compact Disclosure is used for three groups of data: ownership, board characteristics, and chief executive officer characteristics. The ownership data is extracted for beneficial investors. Compact Disclosure retrieves this data from Spectrum which relies on insider trading reports (SEC Forms 3 and 4). Anderson and Lee (1997, (1997) in their study of block ownership, argue that the data on the holdings of the beneficial investors are inconsistent because Spectrum data is stale (i.e., it is not updated enough to reflect the most recent holdings). I address this problem in two ways. First, rather than using the percentage holding of these beneficial investors, I construct an indicator variable, which indicates if the firm has at least one of these investors. Second, I test the robustness of the results with the blockholder data from Andrew Metrick's website. They have compiled this data from the Compact Disclosure (1996 to 2001) and cleaned it to eliminate the inconsistencies.

Compact Disclosure compiles the information regarding the board characteristics and managementteam characteristics, such as directors' and officers' names, ages, titles, and salaries from proxy statements (formatted as DO, and NA, respectively, in Compact Disclosure). I use this data to construct the board size, median director age, and to classify the directors as insiders and outsiders. The classification is based on two methods. The first method is to use the director titles to determine whether a director should be classified as an insider or not. Anybody who carries one of these titles is considered an insider (the spelling errors are corrected before the classification):

1. Assistant general counsel

2. Assistant general manager

3. Assistant secretary

4. Assistant to the president

5. Assistant to the treasurer

6. Assistant vice president

7. Chief accounting officer

8. Chief administrative officer

9. Chief corporate staff officer

10. Chief counsel

11. Chief engineer

12. Chief executive officer

13. Chief financial officer

14. Chief operating officer 
15. Chief scientist

16. Chief strategic officer

17. Clerk

18. Consultant

19. Controller

20. Corporate vice president

21. Deputy president

22. Deputy senior general manager

23. Division president

24. Executive officer

25. Executive vice president

26. Financial vice president

27. First executive vice president

28. First vice president

29. General attorney

30. General manager

31. General officer

32. Group executive vice president

33. Group president

34. Group senior vice president

35. Group vice president

36. Legal counsel

37. Management executive

38. Manager

39. Managing director

40. Operating officer

41. President

42. Principal accounting officer

43. Principal executive officer

44. Principal financial officer

45. Secretary

46. Senior administrative officer

47. Senior executive vice president

48. Senior financial officer

49. Senior managing director

50. Senior vice president

51. Statutory auditor

52. Subsidiary officer

53. Treasurer

54. Vice president

The second method is to match the director names and the officer names. The results presented in this paper follow the first method.

Similar to the construction of the board characteristics, characteristics of officers, including officer age and CEO-chairman duality is constructed from the proxy statements compiled by Compact Disclosure. 


\section{Appendix 2: Target leverage}

Dependent variables are book and market leverage. The coefficient estimates are from a Tobit regression model.

\begin{tabular}{lccccc} 
& \multicolumn{2}{c}{ Book leverage } & \multicolumn{2}{c}{ Market leverage } \\
\hline Market/Book & $-0.022^{* * *}$ & {$[33.92]$} & & $-0.069 * * *$ & {$[108.12]$} \\
Prop., plant, and equip. & $0.070^{* * *}$ & {$[16.66]$} & & $0.072 * * *$ & {$[17.25]$} \\
R\&D & $-0.048^{* * *}$ & {$[11.43]$} & $-0.031^{* * *}$ & {$[7.62]$} \\
R\&D indicator (=1 if R\&D=0) & $0.042^{* * *}$ & {$[20.59]$} & $0.061 * * *$ & {$[30.10]$} \\
Selling expense & $-0.011^{* * *}$ & {$[4.47]$} & $-0.032 * * *$ & {$[13.71]$} \\
EBITDA & $-0.363^{* * *}$ & {$[57.99]$} & $-0.405^{* * *}$ & {$[70.08]$} \\
Size & $0.034 * * *$ & {$[76.34]$} & $0.017 * * *$ & {$[38.11]$} \\
Observations & 71954 & & 75156 & \\
Probability $>\chi^{2}$ & 0.000 & & 0.000 & \\
\hline
\end{tabular}

\begin{tabular}{lcccccc} 
& $\mathrm{N}$ & Mean & St.D. & p50 & $\min$ & $\max$ \\
\hline Book leverage deficit & 26455 & -0.025 & 0.180 & -0.034 & -0.631 & 0.745 \\
Change in book leverage & 26455 & 0.013 & 0.158 & 0.006 & -0.848 & 0.939 \\
Target book leverage & 26455 & 0.484 & 0.090 & 0.489 & 0.137 & 0.810 \\
Market leverage deficit & 27675 & -0.048 & 0.183 & -0.078 & -0.607 & 0.647 \\
Change in market leverage & 27675 & 0.017 & 0.193 & 0.013 & -0.843 & 0.919 \\
Target market leverage & 27675 & 0.414 & 0.112 & 0.425 & 0.062 & 0.847 \\
\hline
\end{tabular}




\section{Appendix 3: Endogenous switching model with unknown sample separation}

Estimation technique follows the endogenous switching model with unknown sample separation presented in Maddala (1986) where the endogenous selection is based on observed characteristics that are correlated with the latent characteristic (managerial discretion).

The model consists of three equations: the selection equation, and two structural regressions that model changes in the debt ratio (Equation 2). The selection equation is:

$$
\mathrm{Z}_{i, t} \mathrm{~V}+\mathrm{u}_{i, t}
$$

which models the latent variable (managerial discretion) as a function of a function of blockholder ownership, board size, director age, CEO-chairman duality, board independence, and CEO age.

Although the regimes are not directly observable, the model assumes that the value of the latent variable separates these two regimes such that observations with

$$
\mathrm{Z}_{i, t} \mathrm{\gamma}+\mathrm{u}_{i, t} \geq 0
$$

into high-discretion regime and those with

$$
\mathrm{Z}_{i, t} \mathrm{\gamma}+\mathrm{u}_{i, t}<0
$$

into low-discretion regime. The likelihood function for each observation is as follows.

$$
\begin{aligned}
l_{i t}= & \operatorname{Pr}\left(u_{i t}<-Z \gamma \mid \varepsilon_{1 i t}=D e b t_{1 i[t, t-3]}-X \beta_{1}\right) \times \operatorname{Pr}\left(\varepsilon_{1 i t}=D e b t_{1 i[t, t-3]}-X \beta_{1}\right)+ \\
& +\operatorname{Pr}\left(u_{i t} \geq-Z \gamma \mid \varepsilon_{2 i t}=D e b t_{2 i[t, t-3]}-X \beta_{2}\right) \times \operatorname{Pr}\left(\varepsilon_{2 i t}=D e b t_{2 i[t, t-3]}-X \beta_{2}\right)
\end{aligned}
$$

Assuming normally distributed error terms, the log-likelihood function for each observation i,t is given by

$$
\ln l_{i t}=\ln \left\{\Phi\left(\frac{-Z i t \gamma-\frac{\rho_{1}}{\sigma_{1}} \varepsilon_{1 i t}}{\sqrt{1-\rho_{1}^{2}}}\right) \phi\left(\varepsilon_{1 i t}, \sigma_{1}\right)+\left[1-\Phi\left(\frac{-Z i t \gamma-\frac{\rho_{2}}{\sigma_{2}} \varepsilon_{2 i t}}{\sqrt{1-\rho_{2}^{2}}}\right) \phi\left(\varepsilon_{2 i t}, \sigma_{2}\right)\right]\right\}
$$

In (A3.5), $\phi($.$) is the normal density function, \Phi($.$) is the standard normal cumulative distribution$ function, $\varepsilon_{1}$ and $\varepsilon_{2}$ are the error terms from Equation (2) for the first and the second regime respectively, $\sigma_{1}$ and $\sigma_{2}$ are the standard deviations of $\varepsilon_{1}$ and $\varepsilon_{2}$ respectively, and $\rho_{1}$ and $\rho_{2}$ are the correlations of $u$ with $\varepsilon_{1}$ and $\varepsilon_{2}$ respectively. 


\section{References}

Admati, Anat R., Paul Pfleiderer, and Josef Zechner, 1994, Large shareholder activism, risk sharing, and financial market equilibrium, Journal of Political Economy 102, 1097-1130.

Agrawal, Anup, and Charles R. Knoeber, 1996, Firm performance and mechanisms to control agency problems between managers and shareholders, Journal of Financial and Quantitative Analysis 31, 377-397.

Almazan, Andres, Javier Suarez, and Sheridan Titman, 2006, Stakeholder, transparency and capital structure, (University of Texas at Austin).

Almeida, Heitor, and Murillo Campello, 2007, Financial constraints, asset tangibility, and corporate investment, Review Financial Studies 20, 1429-1460.

Anderson, Ronald C., and D. Scott Lee, 1997, Field guide for research using ownership data, Journal of Financial and Quantitative Analysis 32, 1-11.

Anderson, Ronald C., and D. Scott Lee, 1997, Ownership studies: The data source does matter, Journal of Financial \& Quantitative Analysis 32, 311-29.

Asquith, Paul, and David W. Mullins, 1986, Equity issues and offering dilution, Journal of Financial Economics 15, 61-89.

Auerbach, Alan J., 1985. Real determinants of corporate leverage (University of Chicago Press, Chicago).

Baker, Malcolm, and Jeffrey Wurgler, 2002, Market timing and capital structure, Journal of Finance 57, 1-32.

Barclay, Michael J., and Clifford G. Holderness, 1991, Negotiated block trades and corporate control, Journal of Finance 46, 861-878.

Bebchuk, Lucian A., and Alma Cohen, 2005, The costs of entrenched boards, Journal of Financial Economics 78, 409-433.

Bebchuk, Lucian A., Alma Cohen, and Allen Ferrel, 2004, What matters in corporate governance?, Olin Discussion Paper No. 491 (Harvard Law School).

Becht, Marco, Patrick Bolton, and Ailsa Roell, 2003, Corporate governance and control, in George Constantinides, Milton Harris, and Rene Stulz, eds.: Handbook of the economics of finance (Elsevier).

Berger, Philip G., Eli Ofek, and David L. Yermack, 1997, Managerial entrenchment and capital structure decisions, Journal of Finance 52, 1411-1438.

Berk, Jonathan, Richard Stanton, and Josef Zechner, 2007, Human capital, bankruptcy and capital structure, Working Paper (University of California, Berkeley).

Brickley, James A., Jeffrey L. Coles, and Gregg Jarrell, 1997, Leadership structure: Separating the ceo and chairman of the board, Journal of Corporate Finance 3, 189-220.

Brickley, James A., Jeffrey L. Coles, and Rory L. Terry, 1994, Outside directors and the adoption of poison pills, Journal of Financial Economics 35, 371-390.

Burkart, Mike, Denis Gromb, and Fausto Panunzi, 1997, Large shareholders, monitoring, and the value of the firm, Quarterly Journal of Economics 112, 693-728.

Core, John E., Robert W. Holthausen, and David F. Larcker, 1999, Corporate governance, chief executive officer compensation, and firm performance, Journal of Financial Economics 51, 371-406.

Dlugosz, Jennifer, Rudiger Fahlenbrach, Paul Gompers, and Andrew Metrick, 2006, Large blocks of stock: Prevalence, size, and measurement, Journal of Corporate Finance 12, 594-618.

Donaldson, Gordon 1961. Corporate debt capacity: A study of corporate debt policy and the determination of corporate debt capacity (Harvard Business School, Division of Research, Harvard University). 
Fama, Eugene F., 1980, Agency problems and the theory of the firm, Journal of Political Economy 88, 288-307.

Fama, Eugene F., and Kenneth R. French, 1997, Industry costs of equity, Journal of Financial Economics 43, 153-193.

Fama, Eugene F., and Michael C. Jensen, 1983, Separation of ownership and control, Journal of Law and Economics 26, 301-325.

Flannery, Mark J., and Kasturi P. Rangan, 2006, Partial adjustment toward target capital structures, Journal of Financial Economics 79, 469-506.

Frank, Murray Z., and Vidhan K. Goyal, 2003, Testing the pecking order theory of capital structure, Journal of Financial Economics 67, 217.

Frank, Murray Z., and Vidhan K. Goyal, 2007, Corporate leverage: How much do managers really matter?, Working Paper (Hong Kong University of Science \& Technology).

Friend, Irwin, and Larry H. P. Lang, 1988, An empirical test of the impact of managerial selfinterest on corporate capital structure, Journal of Finance 43, 271-281.

Garvey, Gerald T., and Gordon Hanka, 1999, Capital structure and corporate control: The effect of antitakeover statutes on firm leverage, Journal of Finance 54, 519-546.

Gompers, Paul, Joy Ishii, and Andrew Metrick, 2003, Corporate governance and equity prices, Quarterly Journal of Economics 118, 107-155.

Goyal, Vidhan K., and Chul W. Park, 2002, Board leadership structure and ceo turnover, Journal of Corporate Finance 8, 49-66.

Graham, J. R., and C. R. Harvey, 2001, The theory and practice of corporate finance: Evidence from the field, Journal of Financial Economics 60, 187-243.

Grossman, Sanford J., and Oliver D. Hart, 1980, Takeover bids, the free-rider problem, and the theory of the corporation, Bell Journal of Economics 11, 42-64.

Grossman, Sanford J., and Oliver D. Hart, 1982, Corporate financial structure and managerial incentives, in John McCall, ed.: The economics of information and uncertainty (University of Chicago Press, Chicago).

Grossman, Sanford J., and Oliver D. Hart, 1988, One share-one vote and the market for corporate control, Journal of Financial Economics 20, 175-202.

Hadlock, Charles J., 1998, Ownership, liquidity, and investment, RAND Journal of Economics 29, 487-508.

Hall, Brian J., and Jeffrey B. Liebman, 1998, Are ceos really paid like bureaucrats?, Quarterly Journal of Economics 113, 653-691.

Harris, Milton, and Artur Raviv, 1988, Corporate control contests and capital structure, Journal of Financial Economics 20, 55-86.

Hart, Oliver, and John Moore, 1995, Debt and seniority: An analysis of the role of hard claims in constraining management, American Economic Review 85, 567-585.

Hermalin, Benjamin E., and Michael S. Weisbach, 1988, The determinants of board composition, RAND Journal of Economics 19, 589-606.

Hermalin, Benjamin E., and Michael S. Weisbach, 1998, Endogenously chosen boards of directors and their monitoring of the ceo, American Economic Review 88, 96-118.

Hermalin, Benjamin E., and Michael S. Weisbach, 2003, Boards of directors as an endogenously determined institution: A survey of the economic literature, Economic Policy Review, Federal Reserve Bank of New York 7-26.

Holderness, Clifford G., 2003, A survey of blockholders and corporate control, Federal Reserve Bank of New York Policy Review 51-54.

Hovakimian, Armen, Tim Opler, and Sheridan Titman, 2001, The debt-equity choice, Journal of Financial and Quantitative Analysis 36, 1-24. 
Hu, Xiaoqiang, and Fabio Schiantarelli, 1998, Investment and capital market imperfections: A switching regression approach using u.S. Firm panel data, Review of Economics and Statistics 80, 466-479.

Israel, Ronen, 1992, Capital and ownership structures, and the market for corporate control, Review of Financial Studies 5, 181-198.

Jalilvand, Abolhassan, and Robert S. Harris, 1984, Corporate behavior in adjusting to capital structure and dividend targets: An econometric study, Journal of Finance 39, 127-145.

Jensen, Michael C., 1986, Agency costs of free cash flow, corporate finance, and takeovers, American Economic Review 76, 323-329.

Jensen, Michael C., 1993, The modern industrial revolution, exit, and the failure of internal control systems, Journal of Finance 48, 831-880.

Jensen, Michael C., and William H. Meckling, 1976, Theory of the firm: Managerial behavior, agency costs and ownership structure, Journal of Financial Economics 3, 305-360.

Jung, Kooyul, Yong-Cheol Kim, and Rene M. Stulz, 1996, Timing, investment opportunities, managerial discretion, and the security issue decision, Journal of Financial Economics 42, 159-185.

Kahn, Charles, and Andrew Winton, 1998, Ownership structure, speculation, and shareholder intervention, Journal of Finance 53, 99-129.

Kayhan, Ayla, and Sheridan Titman, 2007, Firms' histories and their capital structures, Journal of Financial Economics 83, 1-32.

Klein, April, 1998, Firm performance and board committee structure, Journal of Law and Economics 41, 275-303.

Lemmon, Michael L., Michael R. Roberts, and Jaime F. Zender, 2008, Back to the beginning: Persistence and the cross-section of corporate capital structure, Journal of Finance forthcoming.

Litov, Lubomir P., and Kose John, 2006, Corporate governance and financing policy: New evidence, Working Paper (Washington University in St. Louis).

Maddala, G. S., 1986. Limited-dependent and qualitative variables in econometrics (Cambridge University Press, New York).

Marsh, Paul, 1982, The choice between equity and debt: An empirical study, Journal of Finance 37, 121-144.

Maug, Ernst, 1998, Large shareholders as monitors: Is there a trade-off between liquidity and control?, Journal of Finance 53, 65-98.

McConnell, John J., and Henri Servaes, 1990, Additional evidence on equity ownership and corporate value, Journal of Financial Economics 27, 595-612.

Mehran, Hamid, 1992, Executive incentive plans, corporate control, and capital structure, Journal of Financial and Quantitative Analysis 27, 539-560.

Morck, Randall, Andrei Shleifer, and Robert W. Vishny, 1988, Management ownership and market valuation : An empirical analysis, Journal of Financial Economics 20, 293-315.

Morellec, Erwan, Boris Nikolov, and Norman Schuerhoff, 2008, Capital structure and managerial entrenchment: Evidence from a structural estimation, Working Paper (University of Lausanne).

Myers, Stewart C., 1977, Determinants of corporate borrowing, Journal of Financial Economics 5, 147-175.

NACD, 1996, Blue Ribbon Commission Report on Director Professionalism (National Association of Corporate Directors Washington, DC).

Novaes, Walter, and Luigi Zingales, 1995, Capital structure choice when managers are in control: Entrenchment versus efficiency, NBER Working Papers. 
Petersen, Mitchell A., 2008, Estimating standard errors in finance panel data sets: Comparing approaches, Review of Financial Studies forthcoming.

Ritter, Jay, 2002, Investment banking and securities issues, in George Constantinides, Milton Harris, and Rene Stulz, eds.: Handbook of the economics of finance.

Ross, Stephen A., 1977, The determination of financial structure: The incentive-signaling approach, Bell Journal of Economics 8, 23-40.

Safieddine, Assem, and Sheridan Titman, 1999, Leverage and corporate performance: Evidence from unsuccessful takeovers, Journal of Finance 54, 547-580.

Shleifer, Andrei, and Robert W. Vishny, 1986, Large shareholders and corporate control, Journal of Political Economy 94, 461-488.

Shyam-Sunder, Lakshmi, and Stewart C. Myers, 1999, Testing static tradeoff against pecking order models of capital structure, Journal of Financial Economics 51, 219-244.

Strebulaev, Ilya A., 2007, Do tests of capital structure theory mean what they say?, Journal of Finance 62, 1747-1787.

Stulz, Rene M., 1988, Managerial control of voting rights: Financing policies and the market for corporate control, Journal of Financial Economics 20, 25-54.

Stulz, Rene M., 1990, Managerial discretion and optimal financing policies, Journal of Financial Economics 26, 3-27.

Taggart, Robert A., Jr., 1977, A model of corporate financing decisions, Journal of Finance 32, 1467-1484.

Vafeas, Nikos, 2003, Length of board tenure and outside director independence, Journal of Business Finance \& Accounting 30, 1043-1064.

Weisbach, Michael S., 1988, Outside directors and ceo turnover, Journal of Financial Economics 20, 431-460.

Welch, Ivo, 2004, Capital structure and stock returns, Journal of Political Economy 112, 106-131.

Williamson, Oliver E., 1988, Corporate finance and corporate governance, Journal of Finance 43, 567-591.

Yermack, David, 1996, Higher market valuation of companies with a small board of directors, Journal of Financial Economics 40, 185-211.

Zwiebel, Jeffrey, 1996, Dynamic capital structure under managerial entrenchment, American Economic Review 86, 1197-1215. 
Table 1

Descriptive statistics

This table presents the descriptive statistics for the sample of Compustat firms (with available data in Compact Disclosure and CRSP) spanning from 1988 to 2005. Panel A presents the financial characteristics, firm characteristics, and managerial discretion proxies. Financial characteristics: Book leverage is defined as book debt (total liabilities [181] + preferred stock [10] - deferred taxes [35]) to total assets [6]. Market leverage is book debt scaled by the sum of total assets minus book equity (Total Assets - [Total Liabilities + Preferred Stock] + Deferred Taxes) plus market equity [199*25]. Net equity issue is change in book equity minus change in retained earnings [36] scaled by the beginning period total assets. Net debt issue is change in total assets minus change in net equity minus change in retained earnings scaled by the beginning period total assets. Firm characteristics: Market-tobook is the sum of total assets minus book equity plus market equity scaled by total assets. Property, plant, and equipment is net property, plant, and equipment [8] scaled by total assets. R\&D is the research and development expense [46] scaled by net sales [12] where the missing values are set to zero. R\&D indicator takes the value 1 if $R \& D$ is zero and 0 otherwise. Selling expense is selling expense [189] scaled by net sales. EBITDA is earnings before interest, taxes and depreciation [13] scaled by total assets. Size is the natural logarithm of net sales. 3-year cumulative return is the natural logarithm of the sum of monthly returns over a three year window. Managerial discretion proxies: Five is the holdings of beneficial investors scaled by total shares outstanding. Board size is the number of directors on the board. Director age is the median level director age. CEO-Chair duality is an indicator variable that takes the value one if the chief executive officer is also the chairman of the board of directors. The measure for the outsiders on the board is the number of independent directors scaled by the board size. CEO age is the age of the chief executive officer. The numbers in square brackets represent the Compustat data items. Note that CEO age, director age, and board size is used in the natural logarithmic form in the regressions. The details on the construction of the variables are summarized in Appendix 1. Panel B presents the correlation between the financial characteristics and the firm characteristics and the managerial discretion proxies. Panel $\mathrm{C}$ presents the correlation among the managerial discretion proxies. $*, * *, * * *$ Significantly different from zero at the $10 \%, 5 \%$, and $1 \%$ level, respectively. 
Table 1 (continued)

Descriptive statistics

Panel A: summary statistics

N mean $\quad$ St.D. $\quad$ 550 $\min$ max

\begin{tabular}{lrrrrrr}
\hline Financial characteristics & & & & & & \\
\hline Book leverage & 31103 & 0.461 & 0.210 & 0.462 & 0.003 & 1.000 \\
Market leverage & 31370 & 0.356 & 0.230 & 0.320 & 0.001 & 0.996 \\
Net equity issues & 30829 & 0.070 & 0.259 & 0.008 & -0.176 & 3.109 \\
Net debt issues & 30829 & 0.064 & 0.228 & 0.022 & -0.697 & 1.581 \\
Change in retained earnings & 30862 & 0.010 & 0.147 & 0.030 & -0.966 & 0.392 \\
& & & & & & \\
Firm characteristics & & & & & & \\
\hline Market/Book & 31370 & 1.793 & 1.252 & 1.381 & 0.205 & 9.979 \\
Prop., plant, and equip. & 31370 & 0.290 & 0.221 & 0.230 & 0 & 0.989 \\
R\&D & 31370 & 0.061 & 0.241 & 0 & 0 & 4.724 \\
R\&D indicator (=1 if R\&D=0) & 31370 & 0.506 & 0.500 & 1 & 0 & 1 \\
Selling expense & 31370 & 0.311 & 0.414 & 0.232 & 0.001 & 5.767 \\
EBITDA & 31370 & 0.110 & 0.136 & 0.122 & -1.917 & 1.080 \\
Size & 31370 & 5.447 & 1.821 & 5.353 & -5.298 & 12.701 \\
3-year cum. return & 31370 & 0.118 & 0.912 & 0.182 & -6.254 & 4.257 \\
Managerial discretion proxies & & & & & & \\
\hline Five & 31370 & 0.385 & 0.272 & 0.352 & 0 & 0.990 \\
Board size & 31370 & 7.975 & 2.818 & 8 & 3 & 36 \\
Director age & 31370 & 57.04 & 6.169 & 57.5 & 32.5 & 84 \\
CEO-Chair duality & 31370 & 0.584 & 0.493 & 1 & 0 & 1 \\
Outsiders on the board & 31370 & 0.727 & 0.175 & 0.778 & 0 & 1 \\
CEO age & 31370 & 54.40 & 8.564 & 54 & 27 & 90 \\
\hline
\end{tabular}




\section{Table 1 (continued)}

\section{Descriptive statistics}

Panel B: correlation between the financial characteristics and the firm characteristics and the managerial discretion proxies

\begin{tabular}{|c|c|c|c|c|c|}
\hline & $\begin{array}{l}\text { Book } \\
\text { leverage }\end{array}$ & $\begin{array}{l}\text { Market } \\
\text { leverage }\end{array}$ & $\begin{array}{l}\text { Net debt } \\
\text { issues }\end{array}$ & $\begin{array}{l}\text { Net equity } \\
\text { issues }\end{array}$ & $\begin{array}{l}\text { Change in retained } \\
\text { earnings }\end{array}$ \\
\hline Five & $0.056 * * *$ & $0.115 * * *$ & 0.003 & $-0.061 * * *$ & -0.002 \\
\hline Board size & $0.121 * * *$ & $0.045 * * *$ & $0.020 * * *$ & $-0.031 * * *$ & $0.032 * * *$ \\
\hline Director age & 0.005 & $0.032 * * *$ & $-0.067 * * *$ & $-0.105 * * *$ & $0.056 * * *$ \\
\hline CEO-Chair duality & $0.063 * * *$ & $0.046 * * *$ & $0.021 * * *$ & $-0.025 * * *$ & $0.047 * * *$ \\
\hline Outsiders on the board & $0.027^{* * *}$ & $-0.040 * * *$ & $-0.015 * * *$ & 0.0004 & $-0.030 * * *$ \\
\hline CEO age & $0.030 * * *$ & $0.067 * * *$ & $-0.047 * * *$ & $-0.100 * * *$ & $0.071 * * *$ \\
\hline Market/Book & $-0.241 * * *$ & $-0.589 * * *$ & $0.048 * * *$ & $0.251 * * *$ & $0.082 * * *$ \\
\hline Prop., plant, and equip. & $0.145^{* * *}$ & $0.188 * * *$ & 0.009 & $-0.099 * * *$ & $0.034 * * *$ \\
\hline$R \& D$ & $-0.150 * * *$ & $-0.182 * * *$ & -0.004 & $0.240 * * *$ & $-0.353 * * *$ \\
\hline$R \& D$ indicator $(=1$ if $R \& D=0)$ & $0.195 * * *$ & $0.271 * * *$ & $0.039 * * *$ & $-0.083 * * *$ & $0.093 * * *$ \\
\hline Selling expense & $-0.191 * * *$ & $-0.228 * * *$ & $-0.028 * * *$ & $0.240 * * *$ & $-0.402 * * *$ \\
\hline EBITDA & $-0.051 * * *$ & $-0.154 * * *$ & -0.004 & $-0.207 * * *$ & $0.699 * * *$ \\
\hline Size & $0.297 * * *$ & $0.153 * * *$ & $0.044 * * *$ & $-0.146 * * *$ & $0.216 * * *$ \\
\hline 3-year cum. return & $-0.121 * * *$ & $-0.392 * * *$ & $0.180 * * *$ & $0.142 * * *$ & $0.398 * * *$ \\
\hline
\end{tabular}

Panel C: correlation among the managerial discretion proxies
(1)
(2)
(3)
(4)
(5)

(1) Five

1

(2) Board size

$-0.059 * * * \quad 1$

(3) Director age

$-0.072 * * * \quad 0.173 * * * \quad 1$

(4) CEO-Chair duality

$\begin{array}{llll}-0.033 * * * & 0.014 * * * & 0.023 * * * & 1\end{array}$

(5) Outsiders on the board

$\begin{array}{llll}-0.019 * * * & 0.453 * * * & 0.194 * * * & -0.166 * * *\end{array}$

1

(6) CEO age

$\begin{array}{lllll}-0.058 * * * & 0.095 * * * & 0.476 * * * & 0.248 * * * & -0.073 * * *\end{array}$ 
Table 2:

\section{Managerial discretion and sources of funds}

This table presents the coefficient estimates and t-statistics (in parentheses) estimated using ordinary least squares for the following regression model:

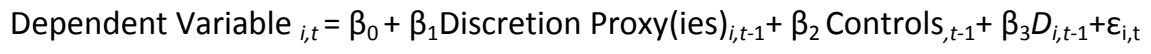

Dependent variables are Net Debt Issues (debt issued minus debt repurchased), Net Equity Issues (equity issued minus equity repurchased) and Changes in Retained Earnings, presented in Panels A-C, respectively. Discretion proxies are: Five (percentage of beneficial ownership), Board size (natural logarithm of board size), Director age (natural logarithm of median director age), CEO-Chair duality (indicator variable), Outsiders on the board (percentage of independent directors on the board), and CEO age (natural logarithm of CEO age). Regressions also include book leverage in the prior period $\left(D_{i, t-1}\right)$. Controls are the year and industry indicator variables. See Table 1 and Appendix 1 for the details on the construction of the variables. In each panel, Models 1 and 2 present the results from a single regression model, where in Model 3 each row presents results from a regression where the discretion proxies is included one at a time in the model. The standard errors are corrected for heteroskedasticity and firm level correlation using cluster analysis. *, **, *** Significantly different from zero at the $10 \%, 5 \%$, and $1 \%$ level, respectively.

Panel A - Dependent variable: net debt issues

\begin{tabular}{|c|c|c|c|c|c|c|c|}
\hline & \multicolumn{2}{|c|}{ Model 1} & \multicolumn{2}{|c|}{ Model 2} & \multicolumn{3}{|c|}{ Model 3} \\
\hline & Coeff. & t-stat. & Coeff. & t-stat. & Coeff. & t-stat. & Adjusted R2 \\
\hline Five & & & $0.009 *$ & {$[1.65]$} & $0.012^{* *}$ & [2.13] & 0.056 \\
\hline Board size & & & $0.014 * * *$ & {$[3.60]$} & $0.008^{* *}$ & {$[2.18]$} & 0.056 \\
\hline Director age & & & $-0.080 * * *$ & {$[-5.33]$} & $-0.114 * * *$ & {$[-8.65]$} & 0.059 \\
\hline CEO-Chair duality & & & $0.010 * * *$ & {$[3.56]$} & $0.007^{* *}$ & {$[2.36]$} & 0.056 \\
\hline Outsiders on the board & & & $-0.014 *$ & {$[-1.68]$} & -0.010 & {$[-1.24]$} & 0.056 \\
\hline CEO age & & & $-0.052 * * *$ & {$[-5.17]$} & $-0.067 * * *$ & {$[-7.84]$} & 0.058 \\
\hline Market/Book & $0.013^{* * *}$ & {$[8.61]$} & $0.012^{* * *}$ & {$[7.83]$} & & & \\
\hline Prop., plant, and equip. & $0.030 * * *$ & {$[3.44]$} & $0.034 * * *$ & [3.98] & & & \\
\hline$R \& D$ & -0.021 & {$[-1.54]$} & -0.020 & {$[-1.46]$} & & & \\
\hline$R \& D$ indicator $(=1$ if $R \& D=0)$ & $0.019 * * *$ & [4.89] & $0.018^{* * *}$ & {$[4.71]$} & & & \\
\hline Selling expense & 0.008 & {$[0.90]$} & 0.008 & {$[0.85]$} & & & \\
\hline EBITDA & $-0.032 * *$ & {$[-2.19]$} & $-0.030 * *$ & {$[-2.03]$} & & & \\
\hline Size & $-0.002 * *$ & {$[-2.32]$} & $-0.002 *$ & {$[-1.66]$} & & & \\
\hline Book leverage & $-0.075 * * *$ & {$[-9.58]$} & $-0.080 * * *$ & {$[-10.30]$} & & & \\
\hline 3-year cum. return & $0.029 * * *$ & [15.10] & $0.030 * * *$ & {$[15.50]$} & & & \\
\hline Observations & 31,551 & & 31,551 & & & & \\
\hline Adjusted R-squared & 0.056 & & 0.061 & & & & \\
\hline Number of firm clusters & 5620 & & 5620 & & & & \\
\hline F-test on discretion proxies & & & $19.97^{* * *}$ & & & & \\
\hline
\end{tabular}


Table 2 (continued):

Managerial discretion and sources of funds

Panel B - Dependent variable: net equity issues

Model 1

Model 2

Model 3

\begin{tabular}{|c|c|c|c|c|c|c|c|}
\hline & \multirow{3}{*}{ Coeff. } & \multirow{3}{*}{ t-stat. } & & & & & \\
\hline & & & Coeff. & t-stat. & Coeff. & \multicolumn{2}{|c|}{ t-stat. Adjusted R2 } \\
\hline & & & $-0.029 * * *$ & {$[-5.56]$} & $-0.027 * * *$ & {$[-5.17]$} & 0.168 \\
\hline Board size & & & $0.018 * * *$ & {$[4.71]$} & $0.012 * * *$ & {$[3.58]$} & 0.167 \\
\hline Director age & & & $-0.039 * * *$ & {$[-2.73]$} & $-0.068 * * *$ & {$[-5.41]$} & 0.168 \\
\hline CEO-Chair duality & & & $0.009 * * *$ & {$[3.40]$} & $0.006^{* *}$ & {$[2.45]$} & 0.167 \\
\hline Outsiders on the board & & & $-0.017^{* *}$ & {$[-2.14]$} & -0.005 & {$[-0.78]$} & 0.167 \\
\hline CEO age & & & $-0.053 * * *$ & {$[-5.41]$} & $-0.052 * * *$ & {$[-6.17]$} & 0.168 \\
\hline Market/Book & $0.052 * * *$ & {$[18.40]$} & $0.050 * * *$ & [18.00] & & & \\
\hline Prop., plant, and equip. & $0.037 * * *$ & {$[4.37]$} & $0.038 * * *$ & {$[4.47]$} & & & \\
\hline$R \& D$ & $0.063 * * *$ & {$[3.24]$} & $0.064 * * *$ & [3.31] & & & \\
\hline$R \& D$ indicator $(=1$ if $R \& D=0)$ & $0.010 * *$ & {$[2.52]$} & $0.010^{* * *}$ & {$[2.62]$} & & & \\
\hline Selling expense & -0.011 & {$[-1.09]$} & -0.014 & {$[-1.33]$} & & & \\
\hline EBITDA & $-0.341 * * *$ & {$[-13.60]$} & $-0.336 * * *$ & {$[-13.40]$} & & & \\
\hline Size & $-0.015^{* * *}$ & {$[-16.10]$} & $-0.017 * * *$ & {$[-15.70]$} & & & \\
\hline Book leverage & $0.076^{* * *}$ & {$[10.60]$} & $0.075^{* * *}$ & {$[10.50]$} & & & \\
\hline 3-year cum. Return & $0.015^{* * *}$ & {$[6.59]$} & $0.015^{* * *}$ & {$[6.74]$} & & & \\
\hline Observations & 31,551 & & 31,551 & & & & \\
\hline Adjusted R-squared & 0.167 & & 0.171 & & & & \\
\hline Number of firm clusters & 5620 & & 5620 & & & & \\
\hline F-test on discretion proxies & & & $18.15^{* * *}$ & & & & \\
\hline \multicolumn{8}{|c|}{ Panel C - Dependent variable: changes in retained earnings } \\
\hline Five & & & 0.004 & [1.19] & 0.003 & {$[1.02]$} & 0.357 \\
\hline Board size & & & $-0.010 * * *$ & {$[-3.54]$} & $-0.008 * * *$ & {$[-3.67]$} & 0.357 \\
\hline Director age & & & $0.016^{*}$ & {$[1.71]$} & $0.019 * *$ & {$[2.22]$} & 0.357 \\
\hline CEO-Chair duality & & & -0.001 & {$[-0.76]$} & -0.001 & {$[-0.25]$} & 0.357 \\
\hline Outsiders on the board & & & 0.001 & {$[0.12]$} & -0.006 & {$[-1.22]$} & 0.357 \\
\hline CEO age & & & 0.009 & {$[1.44]$} & $0.012^{* *}$ & {$[2.13]$} & 0.357 \\
\hline Market/Book & $-0.004 * * *$ & {$[-2.86]$} & $-0.004 * * *$ & {$[-2.60]$} & & & \\
\hline Prop., plant, and equip. & $-0.038 * * *$ & {$[-6.72]$} & $-0.038 * * *$ & {$[-6.69]$} & & & \\
\hline$R \& D$ & $-0.018^{*}$ & {$[-1.76]$} & $-0.019 *$ & {$[-1.82]$} & & & \\
\hline$R \& D$ indicator $(=1$ if $R \& D=0)$ & -0.001 & {$[-0.32]$} & -0.001 & {$[-0.33]$} & & & \\
\hline Selling expense & $-0.033 * * *$ & {$[-5.04]$} & $-0.032 * * *$ & {$[-4.92]$} & & & \\
\hline EBITDA & $0.544^{* * *}$ & [35.40] & $0.543 * * *$ & [35.40] & & & \\
\hline Size & $0.003^{* * *}$ & {$[4.02]$} & $0.003 * * *$ & [4.56] & & & \\
\hline Book leverage & $-0.026 * * *$ & {$[-5.25]$} & $-0.026 * * *$ & {$[-5.14]$} & & & \\
\hline 3-year cum. return & $0.013^{* * *}$ & {$[9.07]$} & $0.013 * * *$ & {$[8.93]$} & & & \\
\hline Observations & 31,954 & & 31,954 & & & & \\
\hline Adjusted R-squared & 0.357 & & 0.360 & & & & \\
\hline Number of firm clusters & 5718 & & 5718 & & & & \\
\hline F-test on discretion proxies & & & $4.13^{* * *}$ & & & & \\
\hline
\end{tabular}


Table 3:

Managerial discretion and debt versus equity financing

This table presents the coefficient estimates and t-statistics (in parentheses) estimated using ordinary least squares for the following regression model:

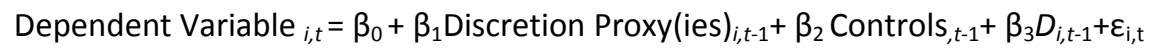

Dependent variables are Debt versus Equity Issuance (debt issued minus equity issued) and Debt versus Equity Repurchase (debt repurchased minus equity repurchased), presented in Panels A and B, respectively. A financing decision is qualified as a repurchase or an issuance decision if the net amount issued (or repurchased) is at least 5 percent or greater than the beginning period total assets, otherwise it is set to zero. Discretion proxies are: Five (percentage of beneficial ownership), Board size (natural logarithm of board size), Director age (natural logarithm of median director age), CEO-Chair duality (indicator variable), Outsiders on the board (percentage of independent directors on the board), and CEO age (natural logarithm of CEO age). Regressions also include book leverage in the prior period $\left(D_{i, t-1}\right)$. Controls are the year and industry indicator variables. See Table 1 and Appendix 1 for the details on the construction of the variables. In each panel, Models 1 and 2 present the results from a single regression model, where in Model 3 each row presents results from a regression where the discretion proxies is included one at a time in the model. The standard errors are corrected for heteroskedasticity and firm level correlation using cluster analysis. ${ }^{*}, * *, * * *$ Significantly different from zero at the $10 \%, 5 \%$, and $1 \%$ level, respectively.

Panel A - Dependent variable: debt issued minus equity issued

\begin{tabular}{|c|c|c|c|c|c|c|c|}
\hline & \multicolumn{2}{|c|}{ Model 1} & \multicolumn{2}{|c|}{ Model 2} & \multicolumn{3}{|c|}{ Model 3} \\
\hline & Coeff. & t-stat. & Coeff. & t-stat. & Coeff. & t-stat. & Adjusted R2 \\
\hline Five & & & $0.024 * * *$ & [4.67] & $0.025^{* * *}$ & [4.81] & 0.089 \\
\hline Board size & & & $-0.010 * * *$ & {$[-2.69]$} & $-0.008 * *$ & {$[-2.51]$} & 0.088 \\
\hline Director age & & & $-0.027^{*}$ & {$[-1.81]$} & $-0.031 * *$ & {$[-2.37]$} & 0.088 \\
\hline CEO-Chair duality & & & -0.001 & {$[-0.40]$} & -0.002 & {$[-0.76]$} & 0.088 \\
\hline Outsiders on the board & & & 0.011 & {$[1.41]$} & 0.001 & {$[0.15]$} & 0.088 \\
\hline CEO age & & & -0.0004 & {$[-0.04]$} & -0.013 & {$[-1.55]$} & 0.088 \\
\hline Market/Book & $-0.030^{* * *}$ & {$[-11.30]$} & $-0.030 * * *$ & {$[-11.20]$} & & & \\
\hline Prop., plant, and equip. & $-0.030 * * *$ & {$[-3.63]$} & $-0.027 * * *$ & {$[-3.31]$} & & & \\
\hline$R \& D$ & -0.035 & {$[-1.62]$} & $-0.036^{*}$ & {$[-1.67]$} & & & \\
\hline$R \& D$ indicator $(=1$ if $R \& D=0)$ & $0.008^{* *}$ & {$[2.34]$} & $0.008^{* *}$ & {$[2.24]$} & & & \\
\hline Selling expense & -0.014 & {$[-1.28]$} & -0.012 & {$[-1.12]$} & & & \\
\hline EBITDA & $0.244 * * *$ & {$[9.33]$} & $0.242 * * *$ & {$[9.30]$} & & & \\
\hline Size & $0.005^{* * *}$ & {$[5.48]$} & $0.007^{* * *}$ & {$[6.67]$} & & & \\
\hline Book leverage & $-0.056 * * *$ & {$[-7.44]$} & $-0.060 * * *$ & {$[-7.81]$} & & & \\
\hline 3-year cum. return & $0.009 * * *$ & [4.09] & $0.009 * * *$ & {$[4.26]$} & & & \\
\hline Observations & 28,043 & & 28,043 & & & & \\
\hline Adjusted R-squared & 0.088 & & 0.090 & & & & \\
\hline Number of firm clusters & 5432 & & 5432 & & & & \\
\hline F-test on discretion proxies & & & $5.80 * * *$ & & & & \\
\hline
\end{tabular}


Table 3 (continued):

Managerial discretion and debt versus equity financing

Panel B - Dependent variable: debt repurchased minus equity repurchased

\begin{tabular}{|c|c|c|c|c|c|c|c|}
\hline & \multicolumn{2}{|c|}{ Model 1} & \multicolumn{2}{|c|}{ Model 2} & \multicolumn{3}{|c|}{ Model 3} \\
\hline & Coeff. & t-stat. & Coeff. & t-stat. & Coeff. & t-stat. & justed R2 \\
\hline Five & & & $-0.004 * *$ & {$[-2.03]$} & $-0.004 * *$ & {$[-2.17]$} & 0.133 \\
\hline Board size & & & $-0.003 * * *$ & {$[-2.63]$} & $-0.003 * *$ & {$[-2.21]$} & 0.133 \\
\hline Director age & & & $0.013 * * *$ & {$[2.64]$} & $0.013 * * *$ & [3.01] & 0.133 \\
\hline CEO-Chair duality & & & 0.0004 & {$[0.44]$} & 0.0004 & {$[0.47]$} & 0.133 \\
\hline Outsiders on the board & & & 0.002 & {$[0.81]$} & 0.0003 & {$[0.10]$} & 0.133 \\
\hline CEO age & & & -0.0002 & {$[-0.063]$} & 0.004 & [1.27] & 0.133 \\
\hline Market/Book & -0.0003 & {$[-0.60]$} & -0.0002 & {$[-0.44]$} & & & \\
\hline Prop., plant, and equip. & $-0.019 * * *$ & {$[-5.85]$} & $-0.019 * * *$ & {$[-5.92]$} & & & \\
\hline$R \& D$ & 0.008 & {$[1.62]$} & 0.008 & {$[1.58]$} & & & \\
\hline$R \& D$ indicator $(=1$ if $R \& D=0)$ & 0.001 & {$[0.51]$} & 0.001 & {$[0.67]$} & & & \\
\hline Selling expense & $-0.008 * * *$ & {$[-3.37]$} & $-0.008 * * *$ & {$[-3.35]$} & & & \\
\hline EBITDA & $-0.034 * * *$ & {$[-5.87]$} & $-0.034 * * *$ & {$[-5.91]$} & & & \\
\hline Size & $-0.006 * * *$ & {$[-18.90]$} & $-0.006 * * *$ & {$[-17.20]$} & & & \\
\hline Book leverage & $0.109 * * *$ & {$[35.20]$} & $0.109 * * *$ & {$[35.30]$} & & & \\
\hline 3-year cum. return & $-0.005 * * *$ & {$[-7.63]$} & $-0.005 * * *$ & {$[-7.72]$} & & & \\
\hline Observations & 31,316 & & 31,316 & & & & \\
\hline Adjusted R-squared & 0.133 & & 0.135 & & & & \\
\hline Number of firm clusters & 5612 & & 5612 & & & & \\
\hline F-test on discretion proxies & & & $3.48^{* *}$ & & & & \\
\hline
\end{tabular}


Table 4:

Managerial discretion and financing decisions: firm fixed effects regressions

This table presents the coefficient estimates and t-statistics (in parentheses) estimated using firm fixed effects for the regression models presented in Tables 2 and 3 where the dependent variables are Net Debt Issues (debt issued minus debt repurchased), Net Equity Issues (equity issued minus equity repurchased), Changes in Retained Earnings, Debt versus Equity Issuance (debt issued minus equity issued) and Debt versus Equity Repurchase (debt repurchased minus equity repurchased). In addition to the variables presented below, the regression model includes year indicator variables. See Table 1 and Appendix 1 for the details on the construction of the variables. The standard errors are corrected for heteroskedasticity and firm level correlation using cluster analysis. ${ }^{*}, * *, * * *$ Significantly different from zero at the $10 \%, 5 \%$, and $1 \%$ level, respectively.

\begin{tabular}{|c|c|c|c|c|c|c|c|c|c|c|}
\hline & \multicolumn{2}{|c|}{ Net debt } & \multicolumn{2}{|c|}{ Net equity } & \multicolumn{2}{|c|}{ Change in RE } & \multicolumn{2}{|c|}{ D vs $E$ issue } & \multicolumn{2}{|c|}{ D vs E Repurchase } \\
\hline & Coeff. & t-stat. & Coeff. & t-stat. & Coeff. & t-stat. & Coeff. & t-stat. & Coeff. & t-stat. \\
\hline Five & $0.017^{*}$ & {$[1.79]$} & $-0.022 * * *$ & {$[-2.71]$} & $-0.020 * * *$ & {$[-4.01]$} & $0.022 * * *$ & {$[2.65]$} & -0.003 & {$[-1.08]$} \\
\hline Board size & 0.008 & [1.45] & $0.017^{* * *}$ & [3.38] & $-0.010 * * *$ & {$[-2.99]$} & -0.009 & {$[-1.62]$} & $-0.005^{* * *}$ & {$[-2.58]$} \\
\hline Director age & -0.036 & {$[-1.48]$} & -0.007 & {$[-0.36]$} & -0.005 & {$[-0.34]$} & -0.010 & {$[-0.51]$} & 0.012 & [1.59] \\
\hline CEO-Chair duality & $0.010 * *$ & {$[2.37]$} & 0.005 & {$[1.46]$} & 0.001 & {$[0.57]$} & 0.000 & {$[0.096]$} & 0.000 & {$[0.31]$} \\
\hline Outsiders on the board & -0.017 & {$[-1.30]$} & $-0.025 * *$ & {$[-2.21]$} & 0.011 & [1.43] & 0.007 & {$[0.63]$} & 0.005 & [1.16] \\
\hline CEO age & $-0.030 * *$ & {$[-1.96]$} & $-0.035^{* *}$ & {$[-2.54]$} & 0.002 & {$[0.18]$} & 0.001 & {$[0.081]$} & 0.000 & [0.01] \\
\hline Market/Book & $0.018^{* * *}$ & [7.34] & $0.057^{* * *}$ & {$[13.3]$} & $0.011^{* * *}$ & {$[6.22]$} & $-0.025 * * *$ & {$[-7.24]$} & 0.001 & [1.27] \\
\hline Prop., plant, and equip. & $0.181^{* * *}$ & {$[6.71]$} & $0.125^{* * *}$ & {$[5.84]$} & $-0.026^{*}$ & {$[-1.89]$} & 0.026 & {$[1.12]$} & $-0.042 * * *$ & {$[-4.44]$} \\
\hline$R \& D$ & -0.034 & {$[-1.50]$} & $0.065^{*}$ & [1.93] & -0.010 & {$[-0.72]$} & 0.017 & {$[0.47]$} & 0.012 & [1.21] \\
\hline$R \& D$ indicator $(=1$ if $R \& D=0)$ & 0.015 & {$[1.27]$} & $0.021^{*}$ & [1.73] & 0.001 & {$[0.085]$} & 0.001 & {$[0.11]$} & -0.001 & {$[-0.36]$} \\
\hline Selling expense & -0.026 & {$[-1.58]$} & $-0.066 * * *$ & {$[-3.27]$} & $-0.033 * * *$ & {$[-3.26]$} & -0.017 & {$[-0.99]$} & -0.002 & {$[-0.41]$} \\
\hline EBITDA & $0.041^{*}$ & {$[1.79]$} & $-0.098 * * *$ & {$[-2.82]$} & $0.380 * * *$ & {$[19.3]$} & $0.135^{* * *}$ & {$[4.48]$} & $-0.017 * *$ & {$[-1.99]$} \\
\hline Size & $-0.062 * * *$ & {$[-12.3]$} & $-0.071 * * *$ & {$[-12.3]$} & $-0.023 * * *$ & {$[-8.39]$} & $-0.009 *$ & {$[-1.82]$} & 0.002 & {$[1.35]$} \\
\hline Book leverage & $-0.495^{* * *}$ & {$[-29.5]$} & $0.205^{* * *}$ & {$[12.10]$} & $0.103^{* * *}$ & {$[11.3]$} & $-0.419 * * *$ & {$[-24.20]$} & $0.213^{* * *}$ & [34.40] \\
\hline 3-year cum. return & $0.009 * * *$ & [3.76] & 0.002 & {$[0.60]$} & $0.003^{*}$ & [1.90] & 0.002 & [0.69] & $-0.003 * * *$ & {$[-3.70]$} \\
\hline Adjusted R-squared & 0.126 & & 0.092 & & 0.124 & & 0.087 & & 0.145 & \\
\hline F-test on discretion proxies & $2.89 * *$ & & $4.10^{* * *}$ & & $4.39 * * *$ & & $1.63 *$ & & $1.76^{*}$ & \\
\hline
\end{tabular}




\section{Table 5:}

\section{Managerial discretion and changes in leverage: Endogenous switching model}

This table presents the results of an endogenous switching model that examines the changes in leverage over a three-year window for low-discretion (Equation 1) and high-discretion (Equation 2) regimes where the selection is based on unknown sample separation using characteristics that are correlated with the latent Managerial Discretion characteristic (Switching regression). The regression model is as follows:

Switching regression:

$$
\text { Managerial Discretion }{ }_{i, t-3}{ }^{*}=z_{i, t-3} \gamma+u_{i, t-3}
$$

High-discretion regime:

$$
\Delta D_{i,[t, t-3]}=\beta_{0}{ }^{H D}+\beta_{1}{ }^{H D} \text { Financing History }{ }_{i,[t, t-3]}+\beta_{2}{ }^{H D}\left(D_{i, t-3}-D^{T}{ }_{i, t-3}\right)+\varepsilon_{i, t}{ }^{H D} \text { when } \mathrm{u}_{i, t-3} \geq-Z_{i, t-3} \gamma
$$

Low-discretion regime:

$$
\Delta D_{i,[t, t-3]}=\beta_{0}{ }^{L D}+\beta_{1}{ }^{L D} \text { Financing History }{ }_{i,[t, t-3]}+\beta_{2}^{L D}\left(D_{i, t-3}-D^{T}{ }_{i, t-3}\right)+\varepsilon_{i, t}{ }^{L D} \text { when } \mathrm{u}_{i, t-3}<-Z_{i, t-3} \gamma
$$

The dependent variable $\Delta D_{i,[t, t-3]}$ is the change in leverage ratio from year t-3 to year t. $Z_{i, t}$ represent the vector of managerial discretion proxies that include Five (percentage of beneficial ownership), Board size (natural logarithm of board size), Director age (natural logarithm of median director age), CEO-Chair duality (indicator variable), Outsiders on the board (percentage of independent directors on the board), and CEO age (natural logarithm of CEO age). Financing history variables are calculated separately for each firm over a 3-year window. $D_{i, t-3}-D_{i, t-3}^{T}$ is leverage deficit which is separated into positive and negative values. Positive Financial Deficit (FD $\geq 0$, equals to Financial Deficit if it is greater than or equal to zero and zero otherwise), Negative Financial Deficit ( $F D<0$, is $(-1)^{*}$ Financial Deficit if it is greater than zero and zero otherwise), Yearly Timing (YT, the covariance between Financial Deficit and Market-to-Book), Long-term Timing (LT, interaction of average Market-to-Book and average Financial Deficit), 3-year cumulative stock return ( $R$, the sum of the natural logarithm of monthly stock returns over a three-year window). Leverage deficit, $D_{i, t-3}-D_{i, t-3,3}^{T}$, which is the difference between observed leverage ratio and the target proxy at the beginning of the observation period (year $t-3$ ) is separated into Positive Leverage Deficit (LD $\geq 0$ equals to Leverage Deficit if it is greater than or equal to zero and zero otherwise) and Negative Leverage Deficit (LD<0, is $(-1) *$ Leverage Deficit if it is greater than zero and zero otherwise). Panel A presents the results for the book leverage and Panel B presents the results for the market leverage. Each panel reports the $P$-value for the hypotheses test on the difference between the coefficient estimates in the high- and low-discretion regimes.

All three equations that define the model are estimated simultaneously using maximum likelihood technique where the standard errors are corrected for heteroskedasticity and firm level correlation using cluster analysis (see Appendix 3$) .{ }^{*}, * *, * * *$ Significantly different from zero at the $10 \%, 5 \%$, and $1 \%$ level, respectively. 
Table 5 (continued):

Managerial discretion and changes in leverage: Endogenous switching model

Panel A: Changes in Book Leverage

Observations: 24,422; Firm clusters: 4,673; Probability> $\chi^{2}: 0.006$

\begin{tabular}{|c|c|c|c|c|c|c|c|c|c|}
\hline Selection Equation & Five & $\begin{array}{c}\text { Board } \\
\text { size }\end{array}$ & $\begin{array}{l}\text { Director } \\
\text { age }\end{array}$ & $\begin{array}{l}\text { CEO- } \\
\text { Chair }\end{array}$ & $\begin{array}{l}\text { Outside } \\
\text { director }\end{array}$ & CEO age & \multirow[b]{4}{*}{$\mathrm{LD}<0$} & \multirow[b]{4}{*}{ Sigma } & \multirow[b]{4}{*}{ Rho } \\
\hline \multirow[b]{3}{*}{ Structural Equation } & 0.011 & 0.298 & 1.108 & -0.030 & -0.537 & 0.619 & & & \\
\hline & {$[0.21]$} & [3.70] & {$[2.70]$} & {$[-0.72]$} & {$[-2.55]$} & {$[2.49]$} & & & \\
\hline & $\mathrm{FD} \geq 0$ & $\mathrm{FD}<0$ & YT & LT & $\mathrm{R}$ & $L D \geq 0$ & & & \\
\hline \multirow[t]{2}{*}{ Low Discretion } & 0.042 & -0.126 & -0.061 & -0.033 & -0.063 & -0.593 & 0.435 & 0.199 & 0.712 \\
\hline & {$[4.76]$} & {$[-4.41]$} & {$[-2.53]$} & {$[-2.73]$} & {$[-15.90]$} & {$[-19.69]$} & [14.36] & [8.94] & [3.88] \\
\hline \multirow[t]{2}{*}{ High Discretion } & 0.188 & -0.469 & -0.173 & -0.105 & -0.036 & -0.122 & 0.172 & 0.068 & -0.218 \\
\hline & [11.12] & {$[-15.67]$} & {$[-2.92]$} & {$[-8.17]$} & {$[-18.01]$} & {$[-6.56]$} & [11.57] & {$[26.52]$} & {$[-0.85]$} \\
\hline$P$-value (Low- High): & 0.000 & 0.000 & 0.140 & 0.001 & 0.000 & 0.000 & 0.000 & & \\
\hline
\end{tabular}

Panel B: Changes in Market Leverage

Observations: 25,696; Firm clusters: 4,862; Probability $>\chi^{2}: 0.000$

\begin{tabular}{|c|c|c|c|c|c|c|c|c|c|}
\hline Selection Equation & Five & $\begin{array}{c}\text { Board } \\
\text { size }\end{array}$ & $\begin{array}{c}\text { Director } \\
\text { age }\end{array}$ & $\begin{array}{l}\text { CEO- } \\
\text { Chair }\end{array}$ & $\begin{array}{l}\text { Outside } \\
\text { director }\end{array}$ & CEO age & \multirow[b]{4}{*}{$L D<0$} & \multirow[b]{4}{*}{ Sigma } & \multirow[b]{4}{*}{ Rho } \\
\hline \multirow[b]{3}{*}{ Structural Equation } & -0.054 & 0.614 & 2.026 & -0.038 & -0.891 & 1.018 & & & \\
\hline & {$[-0.76]$} & {$[9.25]$} & {$[9.12]$} & {$[-0.89]$} & {$[-6.76]$} & {$[7.04]$} & & & \\
\hline & $\mathrm{FD} \geq 0$ & $\mathrm{FD}<0$ & $\mathrm{YT}$ & $\mathrm{LT}$ & $\mathrm{R}$ & $\mathrm{LD} \geq 0$ & & & \\
\hline \multirow[t]{2}{*}{ Low Discretion } & 0.082 & -0.221 & -0.055 & -0.058 & -0.128 & -0.441 & 0.277 & 0.122 & 0.051 \\
\hline & [16.55] & {$[-9.51]$} & {$[-4.31]$} & {$[-10.47]$} & {$[-57.54]$} & {$[-15.12]$} & [16.85] & {$[60.78]$} & {$[0.70]$} \\
\hline \multirow[t]{2}{*}{ High Discretion } & 0.209 & -0.411 & -0.161 & -0.055 & -0.197 & -0.104 & 0.174 & 0.049 & 0.084 \\
\hline & {$[20.02]$} & {$[-20.60]$} & {$[-4.87]$} & {$[-7.16]$} & {$[-106.67]$} & {$[-8.96]$} & {$[17.41]$} & [31.91] & [1.22] \\
\hline$P$-value (Low- High): & 0.000 & 0.000 & 0.003 & 0.000 & 0.000 & 0.000 & 0.000 & & \\
\hline
\end{tabular}


Table 6:

Economic significance of the effect of managerial discretion on capital structure dynamics

This table presents the economic significance of the results presented in Table 5. For the selection equation, it presents the percentage change in the predicted propensity of being in the high-discretion regime due to a one standard deviation increase in the discretion proxy where the values of the variables in the base case are set equal to their sample mean. For the structural equation, it presents the percentage change in the leverage ratio due to a one standard deviation increase in the right hand side variable. Panel A presents the results for the book leverage and Panel B presents the results for the market leverage.

Panel A: Changes in Book Leverage

\begin{tabular}{lccccccc}
$\begin{array}{l}\text { The percentage change in the likelihood } \\
\text { of being in the high discretion regime }\end{array}$ & Five & $\begin{array}{c}\text { Board } \\
\text { size }\end{array}$ & $\begin{array}{c}\text { Director } \\
\text { age }\end{array}$ & $\begin{array}{c}\text { CEO- } \\
\text { Chair }\end{array}$ & $\begin{array}{c}\text { Outside } \\
\text { director }\end{array}$ & CEO age & \\
\cline { 2 - 7 } & -0.76 & 9.21 & 9.88 & 1.514 & -9.28 & 7.47 & \\
\cline { 2 - 7 } The percentage change in leverage & FD 20 & FD<0 & YT & LT & R & LD $\geq 0$ & LD $<0$ \\
\hline Low Discretion & 2.98 & -1.26 & -0.70 & -2.07 & -5.62 & -6.10 & 4.66 \\
High Discretion & 13.42 & -4.72 & -1.98 & -6.50 & -3.17 & -1.26 & 1.84 \\
\hline
\end{tabular}

Panel B: Changes in Market Leverage

\begin{tabular}{|c|c|c|c|c|c|c|c|}
\hline $\begin{array}{l}\text { The percentage change in the likelihood } \\
\text { of being in the high discretion regime }\end{array}$ & Five & $\begin{array}{l}\text { Board } \\
\text { size }\end{array}$ & $\begin{array}{l}\text { Director } \\
\text { age }\end{array}$ & $\begin{array}{l}\text { CEO- } \\
\text { Chair }\end{array}$ & $\begin{array}{l}\text { Outside } \\
\text { director }\end{array}$ & CEO age & \\
\hline & -2.47 & 18.67 & 17.69 & 1.85 & -14.17 & 12.03 & \\
\hline The percentage change in leverage & $F D \geq 0$ & $\mathrm{FD}<0$ & YT & LT & $\mathrm{R}$ & $L D \geq 0$ & $\mathrm{LD}<0$ \\
\hline Low Discretion & 6.16 & -2.33 & -0.65 & -3.75 & -11.96 & -4.51 & 3.02 \\
\hline High Discretion & 15.63 & -4.34 & -1.89 & -3.57 & -18.36 & -1.06 & 1.89 \\
\hline
\end{tabular}


Table 7:

Managerial discretion and changes in leverage: Robustness of the discretion measures

This table presents the results of an endogenous switching model that examines the changes in leverage over a three-year window for low- and high-discretion regimes where the selection is based on unknown sample separation using characteristics that are correlated with the latent Managerial Discretion characteristic (Switching regression). The analysis is the same as the one reported in Table 5 except that the set of proxies used to identify the latent Managerial Discretion characteristic includes G-Index in addition to the ones used in Table 5. Panel A presents the results for book leverage and Panel B presents the results for market leverage. Each panel reports the $P$-value for the hypotheses test on the difference between the coefficient estimates in the high- and low-discretion regimes.

Panel A: Changes in Book Leverage

Observations: 4,080; Firm clusters: 1,085; Probability $>\chi^{2}: 0.000$

\begin{tabular}{|c|c|c|c|c|c|c|c|c|c|}
\hline \multirow[t]{3}{*}{ Selection Equation } & Five & $\begin{array}{l}\text { Board } \\
\text { size }\end{array}$ & $\begin{array}{c}\text { Director } \\
\text { age }\end{array}$ & $\begin{array}{l}\text { CEO- } \\
\text { Chair }\end{array}$ & $\begin{array}{l}\text { Outside } \\
\text { director }\end{array}$ & CEO age & G-Index & \multirow[b]{4}{*}{ Sigma } & \multirow[b]{4}{*}{ Rho } \\
\hline & 0.254 & 0.395 & 1.049 & -0.002 & -0.441 & 0.175 & 0.042 & & \\
\hline & [1.68] & [3.99] & {$[2.07]$} & {$[-0.02]$} & {$[-1.76]$} & {$[0.56]$} & [3.17] & & \\
\hline Structural Equation & $\mathrm{FD} \geq 0$ & $\mathrm{FD}<0$ & YT & $\mathrm{LT}$ & $\mathrm{R}$ & $\mathrm{LD} \geq 0$ & $\mathrm{LD}<0$ & & \\
\hline \multirow[t]{2}{*}{ Low Discretion } & 0.016 & -0.179 & -0.086 & -0.036 & -0.064 & -0.480 & 0.323 & 0.168 & 0.793 \\
\hline & {$[0.98]$} & {$[-2.89]$} & {$[-1.57]$} & {$[-1.72]$} & {$[-9.75]$} & {$[-8.98]$} & [7.04] & {$[17.38]$} & [15.72] \\
\hline \multirow[t]{2}{*}{ High Discretion } & 0.220 & -0.287 & -0.252 & -0.073 & -0.038 & -0.071 & 0.210 & 0.057 & 0.372 \\
\hline & [7.28] & {$[-3.84]$} & {$[-3.78]$} & {$[-3.13]$} & {$[-7.44]$} & {$[-1.50]$} & [8.29] & [15.90] & [2.33] \\
\hline$P$-value (Low- High): & 0.000 & 0.000 & 0.140 & 0.001 & 0.000 & 0.000 & 0.000 & & \\
\hline
\end{tabular}

Panel B: Changes in Market Leverage

Observations: 4,221; Firm clusters: 1,115; Probability $>\chi^{2}: 0.000$

\begin{tabular}{|c|c|c|c|c|c|c|c|c|c|}
\hline \multirow[t]{3}{*}{ Selection Equation } & Five & $\begin{array}{l}\text { Board } \\
\text { size }\end{array}$ & $\begin{array}{c}\text { Director } \\
\text { age }\end{array}$ & $\begin{array}{l}\text { CEO- } \\
\text { Chair }\end{array}$ & $\begin{array}{l}\text { Outside } \\
\text { director }\end{array}$ & CEO age & G-Index & \multirow[b]{4}{*}{ Sigma } & \multirow[b]{4}{*}{ Rho } \\
\hline & 0.182 & 0.367 & 0.846 & -0.010 & -0.471 & 0.599 & 0.068 & & \\
\hline & {$[1.00]$} & [3.22] & [1.59] & {$[-0.12]$} & {$[-1.81]$} & [1.79] & [3.20] & & \\
\hline Structural Equation & $F D \geq 0$ & $F D<0$ & YT & LT & $\mathrm{R}$ & $L D \geq 0$ & $\mathrm{LD}<0$ & & \\
\hline \multirow{2}{*}{ Low Discretion } & 0.055 & -0.112 & -0.070 & -0.010 & -0.143 & -0.538 & 0.197 & 0.105 & -0.527 \\
\hline & [3.92] & {$[-2.20]$} & {$[-2.21]$} & {$[-0.74]$} & {$[-22.32]$} & {$[-5.02]$} & [6.68] & {$[8.45]$} & {$[-3.16]$} \\
\hline \multirow[t]{2}{*}{ High Discretion } & 0.246 & -0.405 & -0.116 & -0.082 & -0.208 & -0.069 & 0.189 & 0.043 & -0.412 \\
\hline & [3.75] & {$[-6.21]$} & {$[-2.18]$} & {$[-1.46]$} & {$[-18.19]$} & {$[-2.28]$} & [9.39] & [8.03] & {$[-1.81]$} \\
\hline$P$-value (Low- High): & 0.002 & 0.001 & 0.459 & 0.235 & 0.000 & 0.000 & 0.846 & & \\
\hline
\end{tabular}


Table 8:

Managerial discretion and changes in leverage: Robustness of the discretion measures

This table presents the results of an endogenous switching model that examines the changes in leverage over a three-year window for low- and high-discretion regimes where the selection is based on unknown sample separation using characteristics that are correlated with the latent Managerial Discretion characteristic (Switching regression). The analysis is the same as the one reported in Table 5 except that the set of proxies used to identify the latent Managerial Discretion characteristic includes CEO stock holdings CEO option holdings, and G Index in addition to the ones used in Table 5. Panel A presents the results for book leverage and Panel B presents the results for market leverage. Each panel reports the $P$-value for the hypotheses test on the difference between the coefficient estimates in the high- and low-discretion regimes.

Panel A: Changes in Book Leverage

Observations: 3,557; Firm clusters: 952; Probability $>\chi^{2}: 0.000$

\begin{tabular}{|c|c|c|c|c|c|c|c|c|c|}
\hline Selection Equation & Five & $\begin{array}{c}\text { Board } \\
\text { size }\end{array}$ & $\begin{array}{c}\text { Director } \\
\text { age }\end{array}$ & $\begin{array}{l}\text { CEO- } \\
\text { Chair }\end{array}$ & $\begin{array}{l}\text { Outside } \\
\text { director }\end{array}$ & CEO age & $\begin{array}{c}\text { CEO } \\
\text { Stock H. }\end{array}$ & $\begin{array}{c}\text { CEO } \\
\text { Option H. }\end{array}$ & G-Index \\
\hline & $\begin{array}{r}0.305 \\
{[1.85]}\end{array}$ & $\begin{array}{r}0.349 \\
{[3.69]}\end{array}$ & $\begin{array}{r}0.821 \\
{[1.80]}\end{array}$ & $\begin{array}{c}0.012 \\
{[0.18]}\end{array}$ & $\begin{array}{r}-0.406 \\
{[-1.88]}\end{array}$ & $\begin{array}{r}0.173 \\
{[0.58]}\end{array}$ & $\begin{array}{l}-0.868 \\
{[-1.55]}\end{array}$ & $\begin{array}{l}-1.268 \\
{[-0.35]}\end{array}$ & $\begin{array}{l}0.042 \\
{[3.09]}\end{array}$ \\
\hline$\underline{\text { Structural Equation }}$ & $\mathrm{FD} \geq 0$ & $F D<0$ & $\mathrm{YT}$ & LT & $\mathrm{R}$ & $\mathrm{LD} \geq 0$ & $\mathrm{LD}<0$ & Sigma & Rho \\
\hline \multirow[t]{2}{*}{ Low Discretion } & 0.007 & -0.195 & -0.086 & -0.028 & -0.060 & -0.497 & 0.347 & 0.175 & 0.839 \\
\hline & {$[0.35]$} & {$[-2.52]$} & {$[-1.58]$} & {$[-1.21]$} & {$[-7.85]$} & {$[-8.90]$} & {$[6.69]$} & [16.60] & [21.28] \\
\hline \multirow[t]{2}{*}{ High Discretion } & 0.219 & -0.279 & -0.271 & -0.071 & -0.043 & -0.068 & 0.212 & 0.058 & 0.416 \\
\hline & {$[9.41]$} & {$[-3.44]$} & {$[-4.41]$} & {$[-3.39]$} & {$[-6.86]$} & {$[-1.41]$} & [7.84] & {$[14.02]$} & {$[2.45]$} \\
\hline$P$-value (Low- High): & 0.000 & 0.572 & 0.041 & 0.208 & 0.156 & 0.000 & 0.029 & & \\
\hline
\end{tabular}

Panel B: Changes in Market Leverage

Observations: 3,659; Firm clusters: 973; Probability $>\chi^{2}: 0.000$

\begin{tabular}{cccccccccc} 
& \multicolumn{3}{c}{$\begin{array}{c}\text { Board } \\
\text { Selection Equation }\end{array}$} & Firector & CEO- & Outside & \multicolumn{2}{c}{ CEO } & \multicolumn{2}{c}{ CEO } \\
& size & age & Chair & director & CEO age & Stock H. & Option H. G-Index \\
\hline & 0.088 & 0.356 & 0.832 & 0.028 & -0.453 & 0.645 & -0.148 & -4.835 & 0.074 \\
& {$[0.41]$} & {$[2.78]$} & {$[1.52]$} & {$[0.32]$} & {$[-1.52]$} & {$[1.83]$} & {$[-0.21]$} & {$[-1.33]$} & {$[3.73]$} \\
\hline
\end{tabular}

\begin{tabular}{|c|c|c|c|c|c|c|c|c|c|}
\hline Structural Equation & $F D \geq 0$ & $F D<0$ & YT & LT & $\mathrm{R}$ & $L D \geq 0$ & $L D<0$ & Sigma & Rho \\
\hline \multirow[t]{2}{*}{ Low Discretion } & 0.045 & -0.116 & -0.059 & 0.001 & -0.143 & -0.554 & 0.199 & 0.102 & -0.528 \\
\hline & [3.17] & {$[-2.52]$} & {$[-1.96]$} & {$[0.04]$} & {$[-25.11]$} & {$[-5.65]$} & [6.53] & [11.75] & {$[-3.74]$} \\
\hline \multirow[t]{2}{*}{ High Discretion } & 0.280 & -0.437 & -0.122 & -0.122 & -0.213 & -0.070 & 0.190 & 0.040 & -0.450 \\
\hline & [11.30] & {$[-7.21]$} & {$[-3.25]$} & {$[-5.24]$} & {$[-28.69]$} & {$[-1.90]$} & [8.14] & {$[10.06]$} & {$[-2.12]$} \\
\hline$P$-value (Low- High): & 0.000 & 0.000 & 0.159 & 0.000 & 0.000 & 0.000 & 0.824 & & \\
\hline
\end{tabular}

